\title{
Linked sediment and water-column methanotrophy at a man-made gas blowout in the North Sea: Implications for methane budgeting in seasonally stratified shallow seas
}

\author{
Lea Steinle, ${ }^{1,2^{*}}$ Mark Schmidt, ${ }^{2}$ Lee Bryant, ${ }^{2, a}$ Matthias Haeckel, ${ }^{2}$ Peter Linke, ${ }^{2}$ Stefan Sommer, ${ }^{2}$ \\ Jakob Zopfi, ${ }^{1}$ Moritz F. Lehmann, ${ }^{1}$ Tina Treude, ${ }^{2, b}$ Helge Niemannn ${ }^{1,3^{*}}$ \\ ${ }^{1}$ Department of Environmental Sciences, University of Basel, Basel, Switzerland \\ ${ }^{2}$ GEOMAR, Helmholtz Centre for Ocean Research, Kiel, Germany \\ ${ }^{3}$ CAGE - Centre for Arctic Gas Hydrate, Environment and Climate, Department of Geology, UIT The Arctic University of \\ Norway, Tromsø, Norway
}

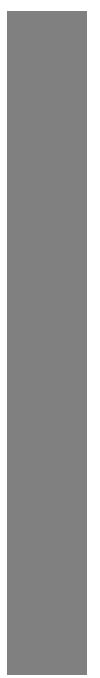

\begin{abstract}
Large quantities of the greenhouse gas methane $\left(\mathrm{CH}_{4}\right)$ are stored in the seafloor. The flux of $\mathrm{CH}_{4}$ from the sediments into the water column and finally to the atmosphere is mitigated by a series of microbial methanotrophic filter systems of unknown efficiency at highly active $\mathrm{CH}_{4}$-release sites in shallow marine settings. Here, we studied $\mathrm{CH}_{4}$-oxidation and the methanotrophic community at a high- $\mathrm{CH}_{4}$-flux site in the northern North Sea (well 22/4b), where $\mathrm{CH}_{4}$ is continuously released since a blowout in 1990. Vigorous bubble emanation from the seafloor and strongly elevated $\mathrm{CH}_{4}$ concentrations in the water column (up to $42 \mu \mathrm{M}$ ) indicated that a substantial fraction of $\mathrm{CH}_{4}$ bypassed the highly active (up to $\sim 2920 \mathrm{nmol} \mathrm{cm}{ }^{-3} \mathrm{~d}^{-1}$ ) zone of anaerobic $\mathrm{CH}_{4}$ oxidation in sediments. In the water column, we measured rates of aerobic $\mathrm{CH}_{4}$-oxidation (up to $498 \mathrm{nM} \mathrm{d}^{-1}$ ) that were among the highest ever measured in a marine environment and, under stratified conditions, have the potential to remove a significant part of the uprising $\mathrm{CH}_{4}$ prior to evasion to the atmosphere. An unusual dominance of the water-column methanotrophs by Type II methane-oxidizing bacteria (MOB) is partially supported by recruitment of sedimentary MOB, which are entrained together with sediment particles in the $\mathrm{CH}_{4}$ bubble plume. Our study thus provides evidence that bubble emission can be an important vector for the transport of sediment-borne microbial inocula, aiding in the rapid colonization of the water column by methanotrophic communities and promoting their persistence close to highly active $\mathrm{CH}_{4}$ point sources.
\end{abstract}

Even though large quantities of methane $\left(\mathrm{CH}_{4}\right)$ are stored in the ocean seafloor as shallow and deep gaseous reservoirs, bound in $\mathrm{CH}_{4}$ hydrates or dissolved in pore water (Wallmann et al. 2012), most recent estimates suggest that oceans account for only a minor fraction of natural $\mathrm{CH}_{4}$ emissions to the atmosphere (Kirschke et al., 2013; IPCC 2013). The

*Correspondence: lea.steinle@unibas.ch, helge.niemann@unibas.ch

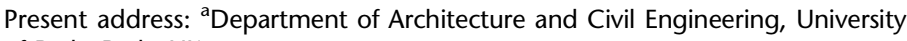
of Bath, Bath, UK

${ }^{b}$ Department of Earth, Planetary \& Space Sciences and Atmospheric \& Oceanic Sciences, University of Los Angeles, Los Angeles, California

Additional Supporting Information may be found in the online version of this article.

Special Issue: Methane Emissions from Oceans, Wetlands, and Freshwater Habitats: New Perspectives and Feedbacks on Climate

Edited by: Kimberly Wickland and Leila Hamdan fact that the marine contribution is rather small can largely be attributed to a series of microbial $\mathrm{CH}_{4}$-oxidation filter systems preventing large-scale $\mathrm{CH}_{4}$ evasion into the atmosphere (Reeburgh 2007; Knittel and Boetius 2009; Kessler et al. 2011; Boetius and Wenzhöfer 2013; Graves et al. 2015; Steinle et al. 2015). In sediments, a large fraction ( $\sim 80 \%$ on average, Knittel and Boetius 2009) of uprising $\mathrm{CH}_{4}$ is oxidized through the sulfate-dependent anaerobic oxidation of methane (AOM, Eq. 1).

$$
\mathrm{CH}_{4}+\mathrm{SO}_{4}^{2-} \rightarrow \mathrm{HCO}_{3}^{-}+\mathrm{HS}^{-}+\mathrm{H}_{2} \mathrm{O} .
$$

AOM is typically mediated by consortia of anaerobic methanotrophic archaea (ANME) and sulfate-reducing bacteria (SRB; Boetius et al. 2000; Orphan et al. 2001; Niemann et al. 2006) though ANME may possibly mediate AOM without partner bacteria (Milucka et al. 2012). Furthermore, aerobic methane-oxidizing bacteria (MOB) consume part of the $\mathrm{CH}_{4}$ flux in oxygenated surface sediments (aerobic oxidation of 


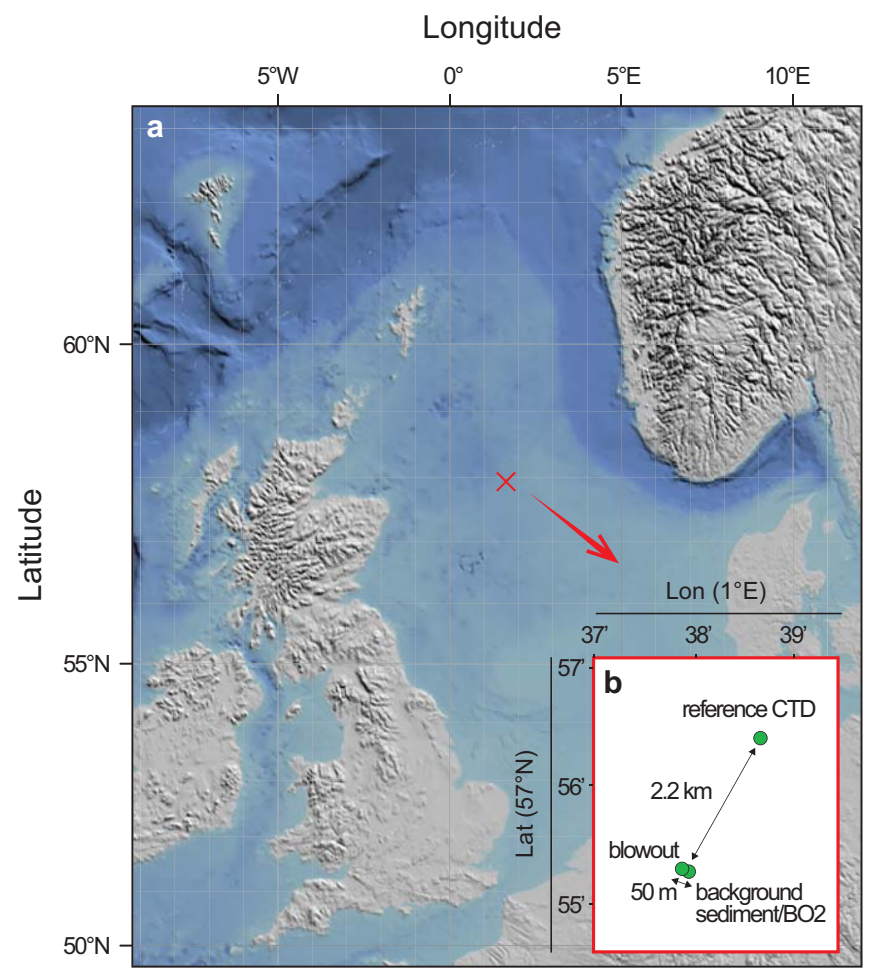

Fig. 1. (a) Location of the Blowout area (red cross) in the northern North Sea (sources: Esri, GEBCO, NOAA, and other contributors). (b) Sectional enlargement showing the relative location and distance (in $\mathrm{km}$ ) of the different sampling sites. [Color figure can be viewed at wileyonlinelibrary.com]

$\mathrm{CH}_{4}-\mathrm{MOx}$; Eq. 2) and represent a second sedimentary filter (Niemann et al. 2006; Boetius and Wenzhöfer 2013).

$$
\mathrm{CH}_{4}+2 \mathrm{O}_{2} \rightarrow \mathrm{CO}_{2}+2 \mathrm{H}_{2} \mathrm{O} \text {. }
$$

These sedimentary filters, however, are less effective in systems characterized by elevated advective fluxes of $\mathrm{CH}_{4}$ (Treude et al. 2003; Niemann et al. 2006; Knittel and Boetius 2009; Steeb et al. 2014). Globally, $0.02 \mathrm{Gt} \mathrm{yr}^{-1}$ (3-3.5\% of the atmospheric budget; Kirschke et al. 2013) of $\mathrm{CH}_{4}$ is estimated to bypass the benthic filter systems and to be released into the ocean water column (Boetius and Wenzhöfer 2013). Within the water column, $\mathrm{CH}_{4}$ can be oxidized aerobically, or anaerobically in the rare case of ocean water column anoxia (Reeburgh 2007).

MOx is performed by MOB, generally belonging to the Gamma-(Type I) or Alphaproteobacteria (Type II) (Hanson and Hanson 1996; Murrell 2010). In oceanic waters, MOB typically belong to the Type I group (Elsaied et al. 2004; Tavormina et al. 2013, 2010; Reed et al. 2009; Håvelsrud et al. 2011; Kessler et al. 2011; Steinle et al. 2015). The first step of MOx is catalyzed by the enzyme particulate or soluble methane mono-oxygenase (pMMO or sMMO, respectively; Semrau et al. 2010, and references therein).

Water-column MOx is the final sink for $\mathrm{CH}_{4}$ before its release to the atmosphere, where it acts as a potent greenhouse gas; however, relatively little is known about the mechanisms and environmental factors controlling the spatiotemporal distribution and activity of pelagic MOB (Tavormina et al. 2010; Kessler et al. 2011; Mau et al. 2013; Crespo-Medina et al. 2014; Steinle et al. 2015). Previous studies showed that MOx and the distribution of Type I and Type II MOB in the oceans are controlled by $\mathrm{CH}_{4}$ and $\mathrm{O}_{2}$ concentrations (Kessler et al. 2011; Mau et al. 2013; CrespoMedina et al. 2014) and trace metal availability (Semrau et al. 2010; Crespo-Medina et al. 2014). Furthermore, advection of water masses harboring distinct microbial communities can constrain prokaryote-biogeographic patterns (Wilkins et al. 2013). Current-induced water mass exchange at $\mathrm{CH}_{4}$ seeps, for example, has been shown to control the distribution of water-column MOx communities, thereby modulating the microbial $\mathrm{CH}_{4}$ filter capacity in the water column (Steinle et al. 2015).

Knowledge of the physical and biogeochemical controls on the activity and distribution of MOB is particularly important for our understanding of the role of shallow water environments (e.g., shelf and coastal seas) in the global marine $\mathrm{CH}_{4}$ budget. In contrast to deep-sea environments, the distance between the seafloor and the atmosphere is short in shallowwater settings, leaving limited time/space for quantitative $\mathrm{CH}_{4}$ consumption to occur prior to its release to the atmosphere (Graves et al. 2015). This effect is amplified when benthic $\mathrm{CH}_{4}$ flux rates are particularly high. Accidents during oil and gas exploration, for example, can lead to the release of excessive amounts of $\mathrm{CH}_{4}$ (and other hydrocarbons) to the ocean water column (Kessler et al. 2011; Sommer et al. 2015). Elevated $\mathrm{CH}_{4}$ evasion is also expected as a result of intensified $\mathrm{CH}_{4}$ hydrate destabilization and permafrost degradation in Arctic shelf environments in the future (Shakhova et al. 2010; Biastoch et al. 2011; Ferré et al. 2012; Berndt et al. 2014); yet it is unknown to which extent the sediment- and watercolumn methanotrophic filter systems will be able to adapt to high $\mathrm{CH}_{4}$ fluxes, and hence to hinder excessive $\mathrm{CH}_{4}$ liberation to the atmosphere (James et al. 2016). In support of evaluating future $\mathrm{CH}_{4}$ seepage scenarios at high-latitude shelf environments, present-day $\mathrm{CH}_{4}$ release sites in other shelf seas, such as those initiated or enhanced by drilling activities, provide a "natural" laboratory for studying the distribution and activity of methanotrophs, and thus the efficiency of the microbial $\mathrm{CH}_{4}$ filter in sediment and the water column in high $\mathrm{CH}_{4}$ flux settings.

Extensive shallow gas accumulations occur in North Sea sediments (Judd and Hovland 2007), and one of the gas pockets at well 22/4b (hereafter referred to as the "Blowout," Fig. 1) was accidentally tapped during drilling operations in November 1990 (Leifer and Judd 2015). This caused a massive blowout (Fox 1995), which left a 60-m wide crater behind (see below), with extensive amounts of $\mathrm{CH}_{4}$ being released from its center until today (Schneider Von Deimling et al. 2015). In this study, we assessed the impact of the 


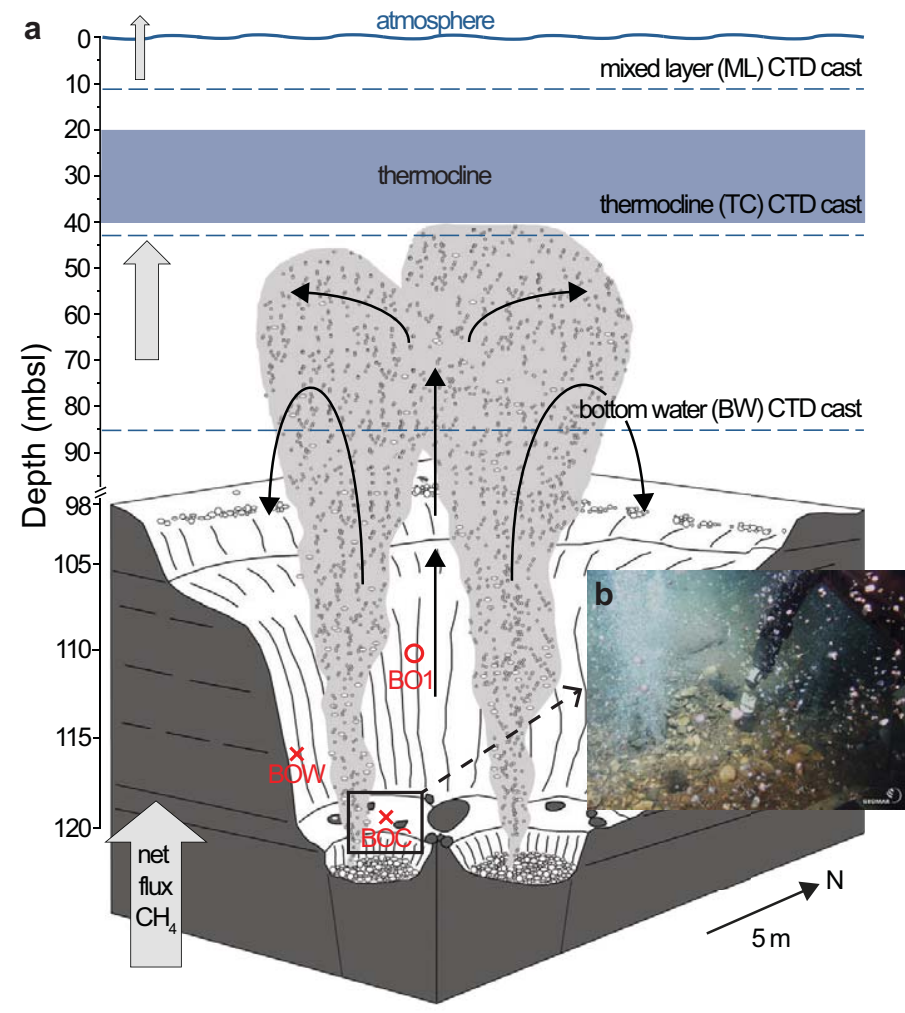

Fig. 2. (a) Schematic representation of the Blowout crater. Isopycnal surfaces for water-column sampling with the CTD are indicated at 11 mbsl (mixed layer, ML), $42 \mathrm{mbsl}$ (thermocline, TC), and $85 \mathrm{mbsl}$ (bottom water grid, BW), respectively. Sediment sampling locations in the center of the crater $(\mathrm{BOC})$ and the crater wall (BOW) are indicated with a red cross. Crater water sampling location with the ROV (BO1) is indicated with a red circle. (b) Photograph of sediment sampling in the center of the crater next to a bubble jet. [Color figure can be viewed at wileyonlinelibrary.com]

persistent and vigorous seabed $\mathrm{CH}_{4}$ release from the Blowout on the methanotrophic community in sediments and the water column. In an interdisciplinary approach combining biogeochemical and molecular tools, we confirm that a stable and highly active AOM community may establish in ocean sediments within $\sim 20$ years after seepage onset (Wilfert et al. 2015). We further demonstrate that the aerobic methanotrophic communities in sediments and in the water column are linked. High water-column MOx rates are supported by the bubble-plume-associated entrainment of sediment-borne $\mathrm{MOB}$, which restock the water-column methanotrophic community and thus help to maintain a highly efficient aerobic water-column $\mathrm{CH}_{4}$ filter.

\section{Material and methods}

\section{Site description}

The Blowout $\left(57^{\circ} 55.41^{\prime} \mathrm{N}\right.$ and $1^{\circ} 37.95^{\prime} \mathrm{E}$, Fig. 1) is located in the northern North Sea at a water depth of $98 \mathrm{~m}$ (Fig. 2a) and consists of $\mathrm{a} \sim 60 \mathrm{~m}$ wide and $\sim 20 \mathrm{~m}$ deep crater (for details see, e.g., Schneider Von Deimling et al. 2007). Although the vigorousness of the gas release has declined since the accident, the Blowout still releases more $\mathrm{CH}_{4}$ (mostly as bubbles, building spiral vortexes, Fig. 2b, Schneider Von Deimling et al. 2015) than any other natural seep in the North Sea (Rehder et al. 1998; Judd 2015). Based on stable carbon isotope analyses, the Blowout emits $\mathrm{CH}_{4}$ of biogenic origin $\left(\delta^{13} \mathrm{C}-\mathrm{CH}_{4}\right.$, ca. $-75 \%$; Sommer et al. 2015). The water column above the Blowout is seasonally stratified, with a well-developed thermocline lasting from approximately April until October/November when deep mixing is induced by the first fall storms (Nauw et al. 2015). Throughout the duration of our study (July/August 2012), the water column above the Blowout was stratified with a well-developed thermocline at about $30 \mathrm{~m}$ water depth (Fig. $3 b)$. In this area, hydrographic processes are highly dynamic with strong tidal currents changing direction approximately every $6 \mathrm{~h}$ (Nauw et al. 2015, and references therein).

\section{Sediment sampling}

Undisturbed surface sediments were recovered by pushcoring with the remotely operated vehicle (ROV) KIEL 6000 (GEOMAR). Biogeochemical and microbiological investigations were conducted at three different sites on parallel push cores sampled in close proximity $(\sim 10 \mathrm{~cm})$ to each other (Table 1). At the Blowout, we sampled sediments in the center of the crater (Fig. 2a,b; BOC), in close vicinity $(\sim 0.5 \mathrm{~m})$ to the emanation point of one of the two main bubble jets, and sediments from the Blowout crater wall (Fig. 2a; BOW). Finally, we retrieved push cores at a background site $50 \mathrm{~m}$ to the southeast of the Blowout crater at a water depth of $99 \mathrm{~m}$. Parameters measured at each sampling site are summarized in Table 1.

\section{Water-column sampling}

Water samples were recovered with a video-guided rosette sampler equipped with twelve 10-liter Niskin bottles and probes for continuous measurements of conductivity, temperature and pressure/depth (CTD rosette sampler; Linke et al. 2015; Table 2). Sampling casts with the CTD rosette sampler will be simply referred to as CTD casts in the following. Both the water within the crater and close to the seafloor was sampled with a 5-liter Niskin bottle mounted to the ROV since sampling with the CTD rosette was not possible. At the Blowout, samples were collected along three surfaces with a grid size of about $200 \times 200 \mathrm{~m}$ (Fig. 2): (i) bottom waters at $85 \mathrm{~m}$ below sea level (mbsl), (ii) the lower part of the thermocline at $42 \mathrm{mbsl}$, and (iii) the upper mixed layer at $11 \mathrm{mbsl}$ above the thermocline. In the following, the different grids will be referred to as (i) bottom water (BW), (ii) thermocline (TC), and (iii) mixed layer grid (ML). We recovered 11 (ML grid) to 12 (BW and TC grid) discrete water samples from each isopycnal surface. Within the Blowout crater, we sampled crater waters $\sim 1 \mathrm{~m}$ away from the bubble stream at $110 \mathrm{mbsl}$ with the ROV (bottle 1=BO1). One additional water sample 


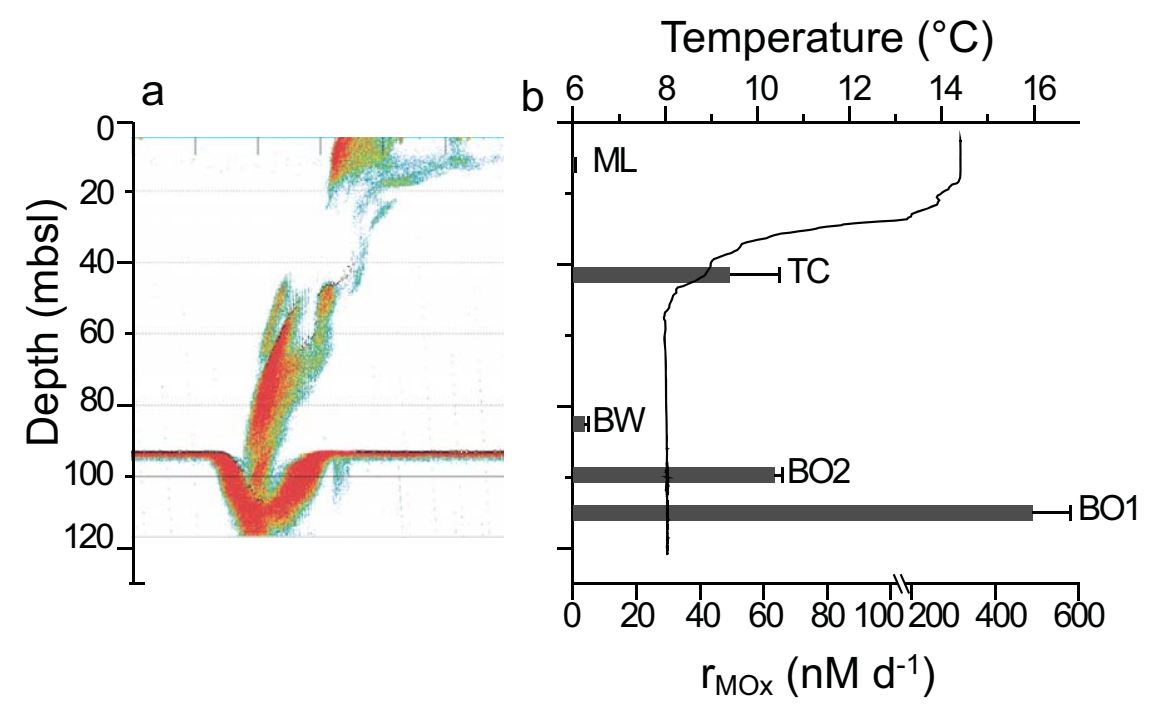

Fig. 3. (a) Sonar image of the Blowout gas flare (Simrad ER60, $38 \mathrm{kHz}$ ). (b) Temperature profile from the ROV-CTD and average water-column MOx rates, calculated from all replicates recovered from a specific depth. Niskin bottle or CTD cast grids are indicated (mixed layer (ML): $n=40$, thermocline (TC): $n=43$, bottom water grid (BW): $n=48, \mathrm{BO} 2: n=4, \mathrm{BO} 1: n=4)$. Error bars represent standard errors. [Color figure can be viewed at wileyonlinelibrary.com]

Table 1. List of sediment sampling locations and parameters measured during cruise CE12010.

\begin{tabular}{|c|c|c|c|c|c|c|c|}
\hline Location & IDs & Position & \#PC & $\begin{array}{l}\text { Length } \\
(\mathrm{cm})\end{array}$ & Geochemistry & $\begin{array}{c}\text { Rates/ } \\
\text { microbiology }\end{array}$ & $\begin{array}{c}\text { Sediment } \\
\text { characteristics }\end{array}$ \\
\hline Blowout center & $\mathrm{BOC}$ & $57^{\circ} 55.293^{\prime} \mathrm{N} 1^{\circ} 37.859^{\prime} \mathrm{E}$ & $3(2)$ & $12-16$ & $\mathrm{CH}_{4}, \mathrm{SO}_{4}^{2-}, \mathrm{H}_{2} \mathrm{~S}$, por. & $\begin{array}{c}\text { AOM, SRR, } \\
\text { CARD-FISH, DNA }\end{array}$ & $\begin{array}{c}\text { Clay, } \\
\text { layer of shells at ca. } 8 \mathrm{~cm}\end{array}$ \\
\hline Blowout wall & BOW & $57^{\circ} 55.291^{\prime} \mathrm{N} 1^{\circ} 37.856^{\prime} \mathrm{E}$ & $4(3)$ & $17-18$ & $\mathrm{CH}_{4}, \mathrm{SO}_{4}^{2-}, \mathrm{H}_{2} \mathrm{~S}$, por. & $\begin{array}{c}\text { AOM, SRR, } \\
\text { CARD-FISH, DNA }\end{array}$ & $\begin{array}{l}\text { Clay, } \\
\text { black layer between } 4-9 \mathrm{~cm}\end{array}$ \\
\hline Background site & - & $57^{\circ} 55.270^{\prime} \mathrm{N} 1^{\circ} 37.888^{\prime} \mathrm{E}$ & $3(2)$ & $18-20$ & $\mathrm{CH}_{4}, \mathrm{SO}_{4}^{2-}, \mathrm{H}_{2} \mathrm{~S}$, por. & $\begin{array}{l}\text { AOM, SRR, } \\
\text { CARD-FISH }\end{array}$ & $\begin{array}{l}\text { Clay, no } \\
\text { color change }\end{array}$ \\
\hline
\end{tabular}

\#PCs denotes the number of total push cores taken at a sampling location. The number of push cores used for rate measurements or microbiological analyses are given in brackets. por. = porosity.

(bottle $2=\mathrm{BO} 2,50 \mathrm{~cm}$ above the seafloor; $98 \mathrm{mbsl}$ ) was recovered with the $\mathrm{ROV} \sim 50 \mathrm{~m}$ away from the crater (i.e., above the sediment background site). A reference CTD cast with Niskin bottle samples recovered from 11, 41, and 85 mbsl was conducted $2.2 \mathrm{~km}$ NNE of the Blowout crater. $\mathrm{CH}_{4}$ concentrations, $\delta^{13} \mathrm{C}-\mathrm{CH}_{4}$ signatures and MOx rates (in quadruplicates) were measured in all samples. For CAtalyzed Reporter Deposition-Fluorescence In Situ Hybridization (CARD-FISH) analyses, we fixed four discrete samples from each CTD grid (Table 2; Fig. 6g-i). Additional CARD-FISH analyses were performed on aliquots from the $\mathrm{BO} 1$ and $\mathrm{BO} 2$ samples, and each depth of the reference CTD. For DNA analysis, we combined 10-20 liter of water from two to four different Niskin bottles ( 5 liter from each bottle) from each grid (Table 2; Fig. 6g-i). From the reference CTD, 20 liter of water from the thermocline was collected for DNA analysis. We could not subsample $\mathrm{BO} 1$ and $\mathrm{BO} 2$ for DNA analyses because of the limited amount of water in the ROV Niskin bottles.
The collected water was filtered through a single Whatman GF/F Glass Microfiber filter $(4.7 \mathrm{~cm} \varnothing$, pore size $\sim 0.7 \mu \mathrm{m})$, and the filters were wrapped in aluminum foil and stored at $-20^{\circ} \mathrm{C}$ until further analyses.

\section{Sediment biogeochemistry}

Sediments were subsampled for concentration measurements of dissolved $\mathrm{CH}_{4}$, sulfate $\left(\mathrm{SO}_{4}^{2-}\right)$, sulfide $\left(\mathrm{H}_{2} \mathrm{~S}\right)$, and porosity. Immediately after recovery, $2 \mathrm{~cm}$ slices of pushcore sediments were extruded with a plunger, and $3 \mathrm{~mL}$ were subsampled with a cut-off syringe and fixed in a saturated $\mathrm{NaCl}$ solution for headspace $\mathrm{CH}_{4}$ concentration measurements by gas chromatography with flame ionization detection (GC-FID) according to Sommer et al. (2009). Five milliliter of wet sediment was sampled for porosity determination by weight difference before and after freeze-drying and the remaining sediment slice $(\sim 50 \mathrm{~mL})$ was transferred to a low pressure-squeezer for pore water extraction. Pore 
Table 2. List of water-column sampling locations parameters sampled during cruise CE12010.

\begin{tabular}{|c|c|c|c|c|c|c|}
\hline Location & IDs & Position & $\begin{array}{l}\text { \#Niskin } \\
\text { bottles }\end{array}$ & $\begin{array}{l}\text { Depth } \\
\text { (mbsl) }\end{array}$ & Geochemistry & $\begin{array}{c}\text { Rates/ } \\
\text { microbiology }\end{array}$ \\
\hline Crater water & BO1 & $57^{\circ} 55.29^{\prime} \mathrm{N} 1^{\circ} 37.85^{\prime} \mathrm{E}$ & 1 (ROV) & 110 & $\mathrm{CH}_{4}(1), \delta^{13} \mathrm{C}-\mathrm{CH}_{4}(1)$ & $\operatorname{MOx}(1), \mathrm{CARD}-\mathrm{FISH}(1)$ \\
\hline Upper mixed layer & ML & $57^{\circ} 55.29^{\prime} \mathrm{N} 1^{\circ} 37.85^{\prime} \mathrm{E}$ & 11 (CTD) & 10.9 & $\mathrm{CH}_{4}(11), \delta^{13} \mathrm{C}-\mathrm{CH}_{4}(11)$ & MOx(11), CARD-FISH(4) DNA(1) \\
\hline Lower thermocline & $\mathrm{TC}$ & $57^{\circ} 55.29^{\prime} \mathrm{N} 1^{\circ} 37.85^{\prime} \mathrm{E}$ & 12 (CTD) & 41.5 & $\mathrm{CH}_{4}(12), \delta^{13} \mathrm{C}-\mathrm{CH}_{4}(12)$ & $\operatorname{MOx}(12)$, CARD-FISH(4) DNA(1) \\
\hline Bottom water grid & BW & $57^{\circ} 55.29^{\prime} \mathrm{N} 1^{\circ} 37.85^{\prime} \mathrm{E}$ & 12 (CTD) & 84.5 & $\mathrm{CH}_{4}(12), \delta^{13} \mathrm{C}-\mathrm{CH}_{4}(12)$ & MOx(12), CARD-FISH(4) DNA(1) \\
\hline
\end{tabular}

*Sampled $50 \mathrm{~m}$ away from the crater above the background sediment site. Numbers in brackets (geochemistry, rates/microbiology) indicate number of samples taken per parameter.

water samples were filtered through $0.45 \mu \mathrm{m}$ regenerated cellulose filters (Whatman) and aliquots were used for onboard analyses of sulfide (photometry of methylene blue; Grasshoff 1999). Dissolved $\mathrm{SO}_{4}^{2-}$ concentrations were determined by ion chromatography onshore. Analytical details are described in Wallmann et al. (2006) and Haffert et al. (2013).

\section{Water-column $\mathrm{CH}_{4}$ concentrations and isotopic composition}

Immediately after CTD/ROV recovery, water samples for $\mathrm{CH}_{4}$ concentration measurements were transferred into $100 \mathrm{~mL}$ serum vials and closed bubble-free with butyl rubber septa. Dissolved $\mathrm{CH}_{4}$ concentrations were determined using headspace extraction (Linke 2012). Briefly, we replaced $10 \mathrm{~mL}$ of water sample with argon and fixed the remaining water sample with $50 \mu \mathrm{L}$ of saturated $\mathrm{HgCl}_{2}$-solution. $\mathrm{CH}_{4}$ concentrations were determined by GC-FID measurements onboard (Vielstädte et al. 2015). Serum vials were then stored at $4^{\circ} \mathrm{C}$ for subsequent stable carbon isotope measurements at GEOMAR by using continuous flow GC combustion-Isotope Ratio Mass Spectrometry (Thermo, MAT253; Vielstädte et al. 2015). All isotope ratios presented here are reported in the conventional $\delta$-notation (i.e., $\delta^{13} \mathrm{C}$ $\mathrm{CH}_{4}$ ) and normalized against the Vienna Pee Dee Belemnite (VPDB) standard. Analytical precision of the reported concentrations and isotopic composition is $\pm 3 \%$ and $\pm 0.3 \%$, respectively.

\section{Methane-oxidation and sulfate-reduction rate measurements}

Anaerobic $\mathrm{CH}_{4}$-oxidation (AOM) and sulfate-reduction (SR) rates in sediments were measured by ex situ whole-core incubation (Jørgensen 1977): small push cores were subsampled from the push cores amended with trace amounts of ${ }^{14} \mathrm{C}$-labelled aqueous $\mathrm{CH}_{4}$ solution $(10 \mu \mathrm{L}, 4 \mathrm{kBq}, \sim 150$ nmol $\mathrm{CH}_{4}$, American Radiolabeled Chemicals) and ${ }^{35} \mathrm{~S}$ labelled sulfate $(25 \mu \mathrm{L}, 20 \mathrm{kBq}$, American Radiolabeled Chemicals, USA), respectively. All incubations were conducted in triplicates for $24 \mathrm{~h}$ at in situ temperature $\left(7-9^{\circ} \mathrm{C}\right)$ in the dark. Incubations were either stopped by fixing extruded sediment slices $(1-3 \mathrm{~cm})$ in $20 \mathrm{~mL} 2.5 \%$ sodium hydroxide $(\mathrm{AOM})$ or in $20 \mathrm{~mL} 20 \%$ zinc acetate (sulfate reduction). $\mathrm{CH}_{4}$-oxidation rates were assessed by ${ }^{14} \mathrm{CH}_{4} \mathrm{com}$ bustion (Treude et al. 2005), ${ }^{14} \mathrm{CO}_{2}$-acidification and determination of rest activity in the remaining sample (Blees et al. 2014). The first-order rate constant $(k)$ was calculated from the fractional tracer turnover with consideration of ${ }^{14} \mathrm{C}$-label transfer into biomass:

$$
k_{(A O M / M O x)}=\frac{\left(A_{\mathrm{CO}_{2}}+A_{R}\right)}{\left(A_{\mathrm{CH}_{4}}+A_{\mathrm{CO}_{2}}+A_{R}\right)} \times \frac{1}{t},
$$

where $A_{\mathrm{CH}_{4}}$ is the activity of remaining ${ }^{14} \mathrm{C}-\mathrm{CH}_{4}$ after incubation, $\mathrm{ACO}_{2}$ is the activity of the generated $\mathrm{CO}_{2}, A_{R}$ is the rest activity (biomass and non-carbonate intermediates), and $t$ is the incubation time. We attribute methane oxidation in sediments to AOM because sediments were generally anoxic. Yet, MOx may have contributed to methane oxidation in the top few millimeters of sediments, which may have been oxic (Niemann et al. 2006, 2009).

SR rates were determined with the cold-chromium distillation method (Kallmeyer et al. 2004) to separate total reduced inorganic sulfur species (TRIS) from unreacted $\mathrm{SO}_{4}^{2-}$. Similar to AOM, the first-order rate constant of SR $\left(k_{S R}\right)$ was then determined from the fractional tracer turnover:

$$
k_{S R}=\frac{A_{T R I S}}{\left(A_{T R I S}+A_{S_{4}^{2-}}\right)} \times \frac{1}{t} \times 1.06,
$$

where $A_{S_{4}^{2-}}$ is the remaining activity in the sulfate pool after incubation, $A_{\text {TRIS }}$ is the activity of the generated sulfide and associated sulfur species, $t$ is the incubation time, and 1.06 the correction factor for the expected ${ }^{35} \mathrm{~S}$-isotope discrimination (Jørgensen and Fenchel 1974). Samples for SR rates were not kept frozen until rates were measured, which may lead to an underestimate of the SR rates (Røy et al. 2014).

For water-column MOx measurements, water samples were transferred bubble-free into $\sim 22 \mathrm{~mL}$ crimp-top vials and sealed with bromobutyl stoppers (Helvoet Pharma), which have been tested not to impede MOx activity (Niemann et al. 2015). Samples were amended with $6 \mu \mathrm{L}$ of a 
${ }^{14} \mathrm{C}-\mathrm{CH}_{4}: \mathrm{N}_{2}$ gas mixture $\left(\sim 0.25 \mathrm{kBq}, \sim 100 \mathrm{nmol} \mathrm{CH}_{4}\right.$, American Radiolabeled Chemicals) and incubated for 2 days at in situ temperature in the dark. Incubations were terminated by fixing the sample in butyl rubber sealed glass bottles with $\sim 1$ g of solid $\mathrm{NaOH}$, and bottles were stored at room temperature until determination of $A_{C_{4}}, A_{C_{2}}$, and $A_{R}$ onshore. First order rate constants were determined analogously as for $\mathrm{CH}_{4}$ oxidation in the sediments. We attribute all water-column $\mathrm{CH}_{4}$-oxidation to MOx since the North Sea water column is generally well oxygenated (Queste et al. 2016). Quadruplicate incubations were performed for all MOx measurements.

Rates of AOM/MOx and SR were then calculated as

$$
\begin{gathered}
r_{A O M / M O x}=k \times\left[\mathrm{CH}_{4}\right], \\
S R R=k_{S R R} \times\left[\mathrm{SO}_{4}^{2-}\right] \times p,
\end{gathered}
$$

where $\left[\mathrm{CH}_{4}\right]$ is the concentration of $\mathrm{CH}_{4}$ in sediments or the water column, respectively, at the beginning of the incubation (plus the $\mathrm{CH}_{4}$ added by ${ }^{14} \mathrm{C}-\mathrm{CH}_{4}$ tracer injection), $\left[\mathrm{SO}_{4}^{2-}\right]$ is the sulfate concentration in the pore water, and $\rho$ is the porosity of the sediment. All rate measurements were corrected for abiotic tracer turnover in killed controls.

\section{CARD-FISH}

Type I and II MOB in the water column were enumerated by CARD-FISH (Pernthaler et al. 2002). In addition, we tested for the presence of Type I and II MOB in surface sediment layers (0$1 \mathrm{~cm}$ sediment depth (cmsd)) in the Blowout center- and the background sediment cores, and for the presence of ANME in sediment layers with maximal AOM rates $(6-10 \mathrm{cmsd})$ of the core from the Blowout center. Fixation of water-column samples was carried out as described in Steinle et al. (2015) and references therein. CARD-FISH was performed as described by Schmale et al. (2015), except that Type I MOB were detected with a mixture of probes M $\gamma 705$-HRP (horseradish peroxidase) and $\mathrm{M} \gamma 84$ HRP (0.3 ng $\mu \mathrm{L}^{-1}$ each), and probe M $\alpha 450$-HRP (0.6 ng $\mu \mathrm{L}^{-1}$ ) was used for detecting Type II MOB (Eller et al. 2001). CARDFISH in sediments was conducted according to Wilfert et al. (2015). CARD-FISH staining of benthic Type I and II MOB was done as for water-column samples.

\section{Molecular analyses}

DNA was extracted from one quarter of a GF/F filter (Whatman, $4.7 \mathrm{~cm} \varnothing$, pore size $\sim 0.7 \mu \mathrm{m}$ ) for water-column samples (Woebken et al. 2007) or $\sim 0.5 \mathrm{~g}$ of wet sediment (Tables 1, 2) with the FastDNA SPIN Kit for soil (MP Biomedicals) using a Precellys24 (Bertin Technologies) cell homogenizer. Partial 16S rRNA gene sequences of Type I and Type II MOB were amplified by PCR with the primer pairs MethT1dF/MethT1bR and 27F/MetT2R, respectively (Lane 1991; Murray et al. 1996; Costello and Lidstrom 1999; Wise et al. 1999). DNA extracts and amplification products were verified by electrophoresis in $0.8-2 \%$ (wt/vol) agarose gels with $0.001 \%$ (vol/vol) Midori Green DNA stain (Nippon Genetics) and quantified fluorometrically using Qubit
(Invitrogen). The community structure of surface sediments and the water column was investigated by denaturing gradient gel electrophoresis (DGGE) following the approach of Tsutsumi et al. (2011). GC-clamped PCR products were separated on a $9 \%$ polyacrylamide gel with a linear denaturing gradient of a $40-70 \%$ (with $100 \%$ denaturants corresponding to $7 \mathrm{M}$ urea and $40 \%(\mathrm{v} / \mathrm{v})$ deionized formamide). Migration was done in a phorU-2 DGGE system (Ingeny International) at a constant temperature of $62^{\circ} \mathrm{C}$ and a voltage of $130 \mathrm{~V}$ for $1 \mathrm{~h}$, followed by $16 \mathrm{~h}$ at $75 \mathrm{~V}$. The gel was stained in $300 \mathrm{~mL}$ TAE (Tris-acetate-EDTA buffer) containing $25 \mu \mathrm{L}$ SYBR Safe (Invitrogen) for $30 \mathrm{~min}$. Dominant bands were excised and DNA was extracted from gel slices with sterile, nuclease-free water at $4^{\circ} \mathrm{C}$ overnight. Extracted DNA was re-amplified, cleaned (Wizard SV Gel and PCR Clean-up System, Promega) and finally cloned in E. coli JM109 using the pGEM-T Easy Vector System (Promega). Inserts were verified by direct clone colony PCR using KAPA2G Robust Polymerase (KAPA Biosystems) and primers SP6/T7. Purified amplicons were sent out for sequencing. Partial 16S rRNA gene sequences have been deposited in the ENA-EBI database under the accession numbers LT591861-LT591887.

\section{Phylogenetic analysis}

Phylogenetic analysis of the partial 16S rRNA gene sequences from isolated DGGE bands was performed in MEGA6 (Tamura et al. 2013). 16S rRNA gene sequences of the nearest uncultivated neighbors were identified and downloaded using SINA (Pruesse et al. 2012), completed by additional sequences of closely related cultivated bacteria as well as outgroup representatives. The sequences were aligned using the Muscle implementation of MEGA. The phylogenetic relationship was inferred using the Maximum Likelihood method based on the Kimura 2-parameter model (Kimura 1980). Initial Neighbor-Joining tree(s) for the heuristic search were based on a pairwise distances matrix calculated with the Maximum Composite Likelihood method. The phylogenetic analysis involved 35 (Type I)/34 (Type II) sequences. Positions with less than 95\% site coverage were eliminated from the analysis, resulting in 159 (Type I)/135 (Type II) positions in the final dataset.

\section{Results}

\section{Sediments}

In sediments of the center of the Blowout, we found saturated $\mathrm{CH}_{4}$ concentrations (after retrieval at ambient pressure) without any clear downcore trends (Fig. 4a). Similarly, pore water sulfate concentrations were high $(\sim 29.5 \mathrm{mM})$ and did not change substantially with depth. No sulfide was detected. AOM and SR rates both peaked between 6 and $11 \mathrm{cmsd}$ with rates of up to 2920 and $2380 \mathrm{nmol} \mathrm{cm} \mathrm{cm}^{-3} \mathrm{~d}^{-1}$, respectively (Fig. 4b,c). At $6 \mathrm{cmsd}$, our CARD-FISH analyses revealed the presence of large aggregates, which only contained ANME-2 cells $\left(6.6 \times 10^{7}\right.$ cells $\left.\mathrm{cm}^{-3}\right)$; however, potentially associated 


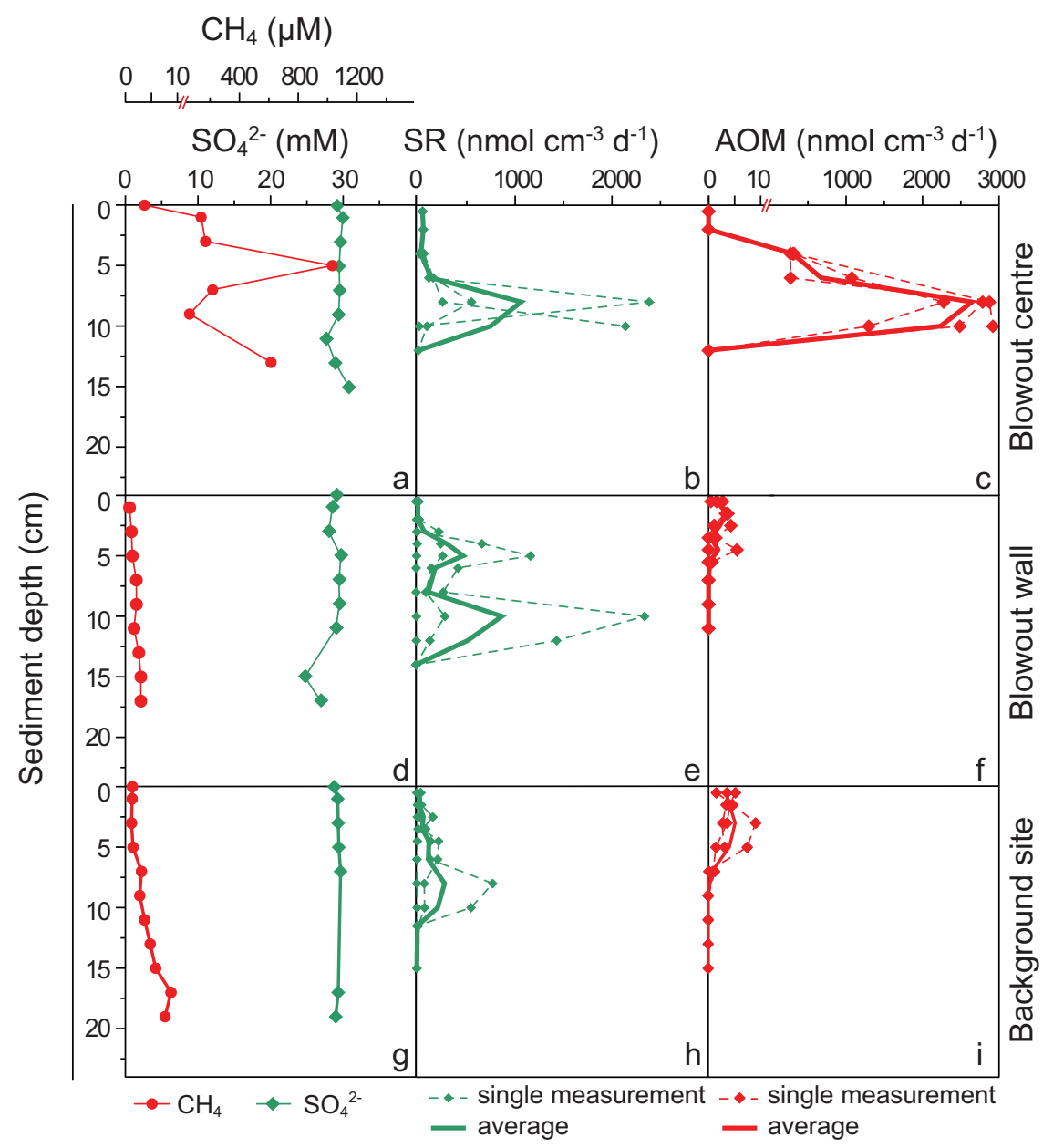

Fig. 4. Sediment geochemical profiles and rate measurements from the bottom of the blowout crater (a-c), blowout wall (d-f), and background site $50 \mathrm{~m}$ away from the blowout $(\mathbf{g}-\mathbf{i})$. Replicate rate measurements are shown individually (dashed lines) and the average value is indicated as a thick, solid line. As sediments were anoxic, we attribute methane oxidation in sediments to AOM with potential contribution from MOx at the sediment surface (Niemann et al. 2009). [Color figure can be viewed at wileyonlinelibrary.com]

SRB could not be observed (Fig. 5a,d). Additionally, some single cells of ANME-1 and -3, and some cell-chains of ANME-1 were detected (all together $<0.3 \times 10^{7}$ cells $\mathrm{cm}^{-3}$ ). In surface sediments (0-1 cmsd), both Type I and II MOB were detect-

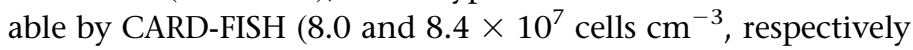
(Fig. 5b,c,e,f), while ANMEs were not detected in this layer. As sediments were anoxic and ANME cells were detected at 6 cmsd, we attribute methane oxidation in sediments primarily to AOM, with a potential contribution from MOx at the sediment surface (Niemann et al. 2009).

In the Blowout wall sediment, $\mathrm{CH}_{4}$ concentrations generally increased with sediment depth (i.e., horizontal penetration depth in the Blowout wall sediment core) reaching $\sim 3$ $\mu \mathrm{M}$ at $17 \mathrm{cmsd}$; yet they were still $\sim 1000$ times lower than in sediment cores retrieved from the crater bottom (Fig. $4 \mathrm{~d}$ ). Sulfate concentrations decreased slightly from seawater concentrations $(\sim 29.5 \mathrm{mM})$ to about $25 \mathrm{mM}$ at $15 \mathrm{cmsd}$
(Fig. 4d). Sulfide could not be detected. We measured only very low $\mathrm{CH}_{4}$-oxidation rates in the upper section of the sediment core $\left(\sim 6 \mathrm{nmol} \mathrm{cm} \mathrm{cm}^{-3} \mathrm{~d}^{-1}\right.$ at $5 \mathrm{cmsd}$, Fig. $\left.4 \mathrm{e}\right)$. In contrast, SR rates were three orders of magnitude higher and showed a double-peak with maximum values of $\sim 1300$ and $\sim 2400 \mathrm{nmol} \mathrm{cm} \mathrm{cm}^{-3} \mathrm{~d}^{-1}$ at 5 and $10 \mathrm{cmsd}$, respectively (Fig. 4f). Note that slumping probably disturbed crater wall sediments, which complicates further interpretation of this data.

At the background site $50 \mathrm{~m}$ away from the crater, downcore $\mathrm{CH}_{4}$ concentrations increased only slightly, reaching $\sim 8 \mu \mathrm{M}$ at the bottom of the core $(17 \mathrm{cmsd}$, Fig. $4 \mathrm{~g})$, and were thus much lower than in nearby crater bottom sediments. Sulfate concentrations were essentially invariant throughout the core and we could not detect sulfide (Fig. $4 \mathrm{~g}$ ). Methanotrophic activity was comparatively low (max. $9 \mathrm{nmol} \mathrm{cm} \mathrm{cm}^{-3} \mathrm{~d}^{-1}$, Fig. 4h) and similar to what was observed for the crater wall sediments. Compared to the other sediment sampling sites, SR rates were relatively 

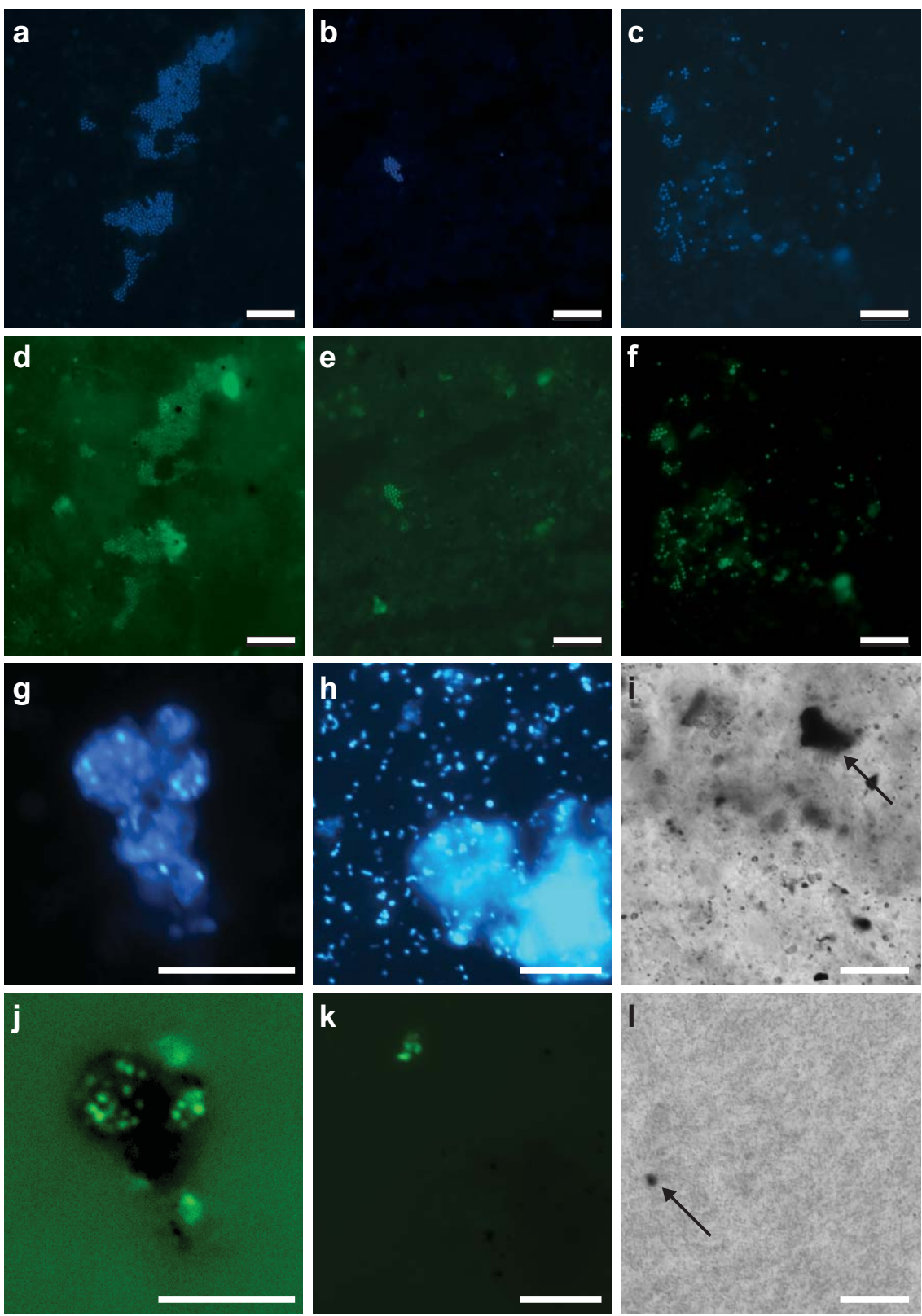

Fig. 5. Micrographs of sediment samples from the Blowout crater bottom and from water samples. (a-f) Epifluorescence micrographs from crater bottom sediments and ( $\mathbf{g - k})$ from the bottom water grid (85 mbsl). Images $\mathbf{a}-\mathbf{c}, \mathbf{g}$, $\mathbf{h}$ are stained with DAPI for total cell counts, and $\mathbf{d - f}$, $\mathbf{j}$, $\mathbf{k}$ with Alexa488 for CARD-FISH using probe ANME-2-538 targeting ANME-2 (d), M $\gamma 705$ and M $\gamma 84$ targeting Type I MOB (e), or M $\alpha 450$ targeting Type II MOB (f, j, k). (a, d) Image of sediment sample from 6 to $10 \mathrm{cmsd}$, and (b, $\mathbf{c}, \mathbf{e}, \mathbf{f})$ from 0 to $1 \mathrm{cmsd}$. (i, I) Unstained transmitted light micrographs from $\mathbf{i}$, within the Blowout crater (BO1) and $\mathbf{I}$, from the bottom water grid (85 mbsl) above the Blowout. Arrows indicate sediment particles. Scale bars represent $10 \mu \mathrm{m}$.

low, with values of $<500 \mathrm{nmol} \mathrm{cm} \mathrm{cm}^{-3} \mathrm{~d}^{-1}$ (Fig. 4i). We found both Type I and Type II MOB in the upper $0-1 \mathrm{~cm}$ of the sediment core with CARD-FISH.

\section{Water column}

Spatial variations of $\mathrm{CH}_{4}$ concentrations and $\delta^{13} \mathbf{C}-\mathrm{CH}_{4}$

We detected the highest $\mathrm{CH}_{4}$ concentration of 42,097 nM within the Blowout crater, just adjacent to the main bubble stream (BO1, Table 3). However, even higher concentrations can be expected closer to the bubble jets. Lower $\mathrm{CH}_{4}$ concentrations were found in the bottom water grid (all concentrations $>500 \mathrm{nM}$; 37,233 nM maximum; Fig. 6c; Table 3) and within the thermocline (>50 nM; 13,526 nM maximum; Fig. 6b; Table 3). While we also found elevated $\mathrm{CH}_{4}$ concentrations (1794 nM) in waters sampled $\sim 0.5 \mathrm{~m}$ above the sediment background site (BO2, Table 3), we did not find indications for active $\mathrm{CH}_{4}$ 


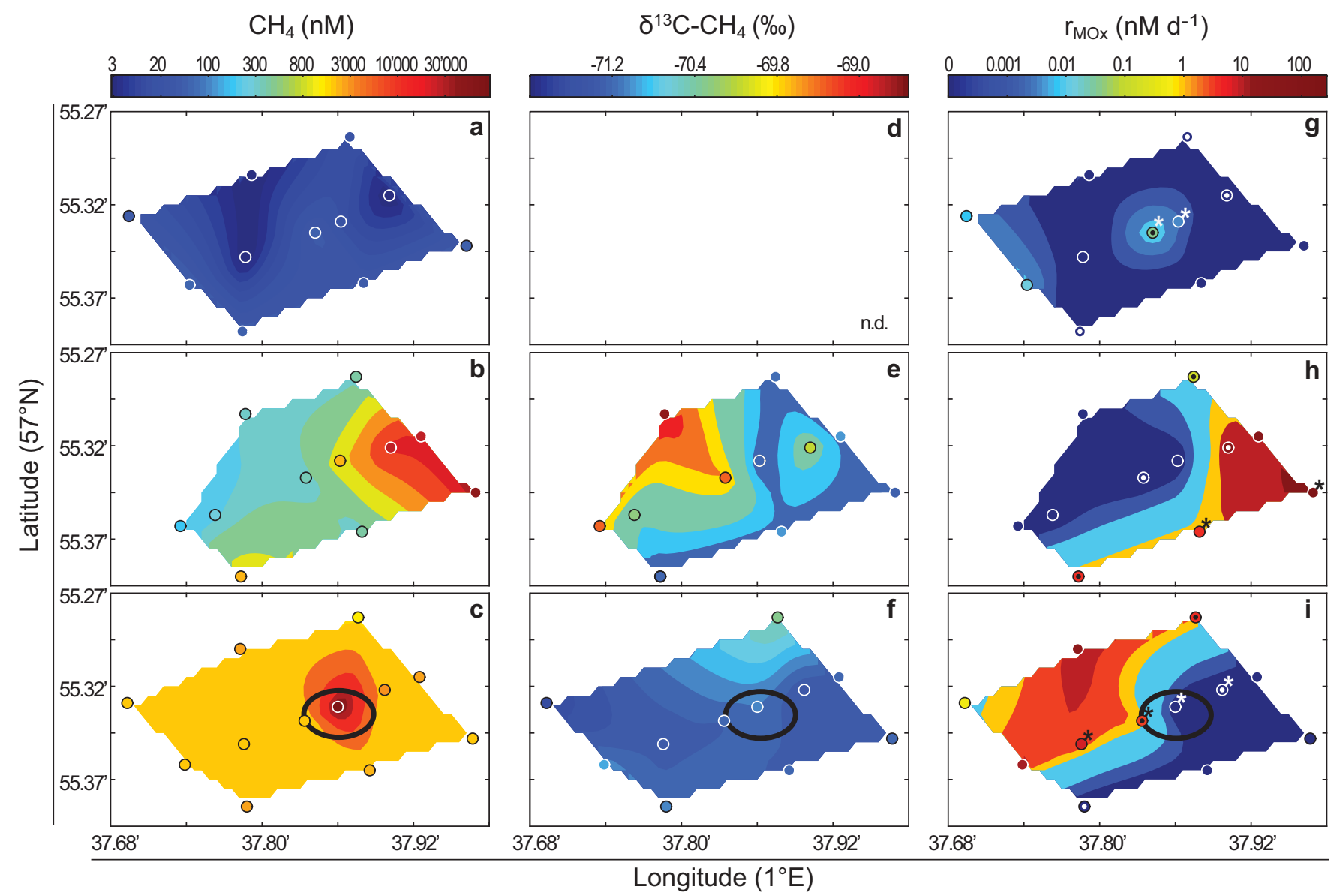

Fig. 6. (a-c) Water-column $\mathrm{CH}_{4}$ concentrations, (d-f) $\delta^{13} \mathrm{C}_{-}-\mathrm{CH}_{4}$ values, and $(\mathbf{g}-\mathbf{i}) \mathrm{MOx}$ rates measured in the bottom water grid (c, $\mathbf{f}$, i), the thermocline $(\mathbf{b}, \mathbf{e}, \mathbf{h})$, and the mixed layer grids $(\mathbf{a}, \mathbf{d}, \mathbf{g})$. Isolines were calculated from triangulation-based linear interpolation of measured values (indicated as circles). Locations, for which rate samples and parallel CARD-FISH samples were recovered are indicated with a dot in the center of the circles $(\mathbf{g}, \mathbf{h}, \mathbf{i})$. Locations additionally sampled for DGGE analysis are indicated with a star $(\mathbf{g}, \mathbf{h}, \mathbf{i})$. The position of the crater is indicated by a black oval in the bottom water plots. Relatively low $\mathrm{CH}_{4}$ concentrations in the mixed layer (6a) precluded $\delta^{13} \mathrm{C}_{-} \mathrm{CH}_{4}$ measurements (detection limit $\sim 20 \mathrm{nM}$ ).

seepage at this site (e.g., gas ebullition). In the mixed layer above the thermocline, $\mathrm{CH}_{4}$ concentrations were comparably low (all $<20 \mathrm{nM}$ ), but even here they were at supersaturation levels (up to eightfold) with respect to the atmospheric equilibrium $(\sim 2.5 \mathrm{nM}) . \delta^{13} \mathrm{C}-\mathrm{CH}_{4}$ values as low as $-71.1 \%$ were detected in crater waters next to the plume (BO1) and similarly negative $\delta$ values were measured in the bottom water grid (Table 3; Fig. 6f). More variable and more positive $\delta^{13} \mathrm{C}-\mathrm{CH}_{4}$ values (up to $-67.5 \%$ ) were detected within the thermocline, particularly in samples with values at the lower end of the $\mathrm{CH}_{4}$ concentration range (Fig. 6e). Samples collected further away from the crater (sample BO2) also showed a slight enrichment in ${ }^{13} \mathrm{C}(-69.3 \%$; Table 3) when compared to $\mathrm{BO} 1$. $\mathrm{CH}_{4}$ concentrations at the reference CTD site were highest at $85 \mathrm{mbsl}(221 \mathrm{nM})$ and decreased to $88 \mathrm{nM}$ within the thermocline (Table 3 ).

\section{Methane oxidation rates}

The vertical distribution of MOx in the water column displayed two maxima: One within the Blowout crater (BO1;
$498 \mathrm{nM} \mathrm{d}^{-1}$ ), and a second one at the thermocline (up to $262 \mathrm{nM} \mathrm{d}^{-1} ; 49 \mathrm{nM} \mathrm{d}^{-1}$ on average; Fig. 3b, 6h, Table 3). In sample $\mathrm{BO} 2, \mathrm{MOx}$ rates were also elevated (up to $63 \mathrm{nM} \mathrm{d}^{-1}$ ) while samples from the bottom water grid showed substantially lower rates with values $<19 \mathrm{nM} \mathrm{d}^{-1}\left(3.5 \mathrm{nM} \mathrm{d}^{-1}\right.$ on average; Figs. 3b, 6i). MOx rates in the mixed layer were low $\left(<0.03 \mathrm{nM} \mathrm{d}^{-1}\right)$. Nevertheless, it has to be noted that, despite generally high $\mathrm{CH}_{4}$ concentrations measured in the bottom water grid and the thermocline, rates were variable, and below detection limit in several samples (Fig. 6, detection limit of $k=0.001 \mathrm{~d}^{-1}$ ). All rates from the reference CTD were below detection limit.

\section{MOB communities in the water column}

The water-column MOB community within the crater, in the bottom water grid and the thermocline was mainly composed of Type II MOB (76-95\% of all MOB, Fig. 5j,k, Fig. 7). Highest cell counts of Type II MOB were observed within the crater $\left(44.8 \times 10^{3}\right.$ cells $\mathrm{mL}^{-1}$; BO1; Fig. 7 , Table 3$)$ and in 
Table 3. Overview of water depth, $\mathrm{CH}_{4}$ concentrations, $\delta^{13} \mathrm{C}-\mathrm{CH}_{4}$ values, $\mathrm{MOx}$ rates, $\mathrm{MOx}$ rate constants, and Type I and II MOB cell numbers in the water column.

\begin{tabular}{|c|c|c|c|c|c|c|}
\hline Parameter: & $\begin{array}{c}\text { Crater } \\
\text { water (BO1) }\end{array}$ & $\begin{array}{c}0.5 \mathrm{~m} \text { above } \\
\text { sediment }(\mathrm{BO} 2)\end{array}$ & $\begin{array}{l}\text { Bottom water } \\
\text { grid (BW) }\end{array}$ & $\begin{array}{c}\text { Thermocline } \\
\text { (TC) }\end{array}$ & $\begin{array}{l}\text { Mixed } \\
\text { layer } \\
\text { (ML) }\end{array}$ & $\begin{array}{c}\text { Reference } \\
\text { CTD (refCTD) }\end{array}$ \\
\hline Water depth (mbsl) & 110 & 97.5 & 85 & 42 & 11 & $11 / 41 / 85$ \\
\hline $\max . \mathrm{CH}_{4}(\mathrm{nM})$ & 42,097 & 1,794 & 37,233 & 13,526 & 21 & 221 \\
\hline $\min . \mathrm{CH}_{4}(\mathrm{nM})$ & - & - & 523 & 57 & $<5$ & 88 \\
\hline $\begin{array}{l}\text { Source } \delta^{13} \mathrm{CCH}_{4} \\
\quad \text { (gas bubble) }(\%)\end{array}$ & -74.8 & - & - & - & - & - \\
\hline $\begin{array}{l}\text { max. } \delta^{13} \mathrm{C} \text { dissolved } \\
\qquad \mathrm{CH}_{4}(\%)\end{array}$ & -71.1 & -69.3 & -69.9 & -67.5 & NA & - \\
\hline $\begin{array}{l}\max . \text { MOx rate } \\
\qquad\left(\mathrm{nM} \mathrm{d}^{-1}\right)\end{array}$ & $498.4( \pm 159.6)$ & $63.3( \pm 5.4)$ & $17.5( \pm 18.1)$ & $261.7( \pm 18.7)$ & $0.03( \pm 0.01)$ & 0 \\
\hline $\begin{array}{l}\text { Average } \mathrm{MOx} \text { rate } \\
\qquad\left(\mathrm{nM} \mathrm{d}^{-1}\right)\end{array}$ & - & - & 3.5 & 49 & 0.006 & - \\
\hline $\begin{array}{l}\max . k \\
\qquad\left(\times 10^{-2} \mathrm{~d}^{-1}\right)\end{array}$ & $1.2( \pm 0.4)$ & $3.5( \pm 0.3)$ & $1.9( \pm 2.0)$ & $2.9( \pm 2.5)$ & $0.2( \pm 0.1)$ & 0 \\
\hline $\begin{array}{l}\text { average } \mathrm{k} \\
\qquad\left(\times 10^{-2} \mathrm{~d}^{-1}\right)\end{array}$ & - & - & $0.5( \pm 0.7)$ & $1.1( \pm 1.3)$ & $0.04( \pm 0.06)$ & 0 \\
\hline $\begin{array}{l}\text { max. Type I MOB } \\
\qquad\left(\times 10^{3} \text { cells } \mathrm{mL}^{-1}\right)\end{array}$ & 0.7 & 0.8 & 0.3 & 0.08 & 0.05 & 0.01 \\
\hline $\begin{array}{l}\text { max. Type II MOB } \\
\qquad\left(\times 10^{3} \text { cells } \mathrm{mL}^{-1}\right)\end{array}$ & 44.8 & 29.3 & 1.3 & 0.9 & - & - \\
\hline
\end{tabular}

the sample taken $50 \mathrm{~m}$ away from the crater $\left(29.3 \times 10^{3}\right.$ cells $\mathrm{mL}^{-1}$; $\mathrm{BO} 2$; Table 3 ). In both the bottom water grid and the thermocline, average Type II cell numbers were $\sim 0.5$ $\times 10^{3}$ cells $\mathrm{mL}^{-1}$ (Table 3 ), but $\sim 100$-fold lower than within the crater. In contrast, average Type I MOB counts differed between the bottom water grid and the thermocline, with higher average cell numbers in the bottom water grid $(0.15$ $\times 10^{3}$ cells $\left.\mathrm{mL}^{-1}\right)$ compared to the thermocline $\left(0.03 \times 10^{3}\right.$ cells $\mathrm{mL}^{-1}$; Fig. 7 , Table 3 ). No Type II MOB and only few Type I MOB $\left(\max .0 .02 \times 10^{3}\right.$ cells $\left.\mathrm{mL}^{-1}\right)$ were observed in the mixed layer (Table 3 ). MOB contributed up to $29 \%$ of total DAPI cell counts in the water column at the Blowout (29\% BO1; 7.3\% BO2; <0.3\% bottom water grid, and thermocline; $<0.01 \%$ mixed layer). We observed abundant sediment particles on the filters of the BO1 (Fig. 5i) and $\mathrm{BO} 2$ samples, whereas only a few particles were present on filters from the bottom water grid (Fig. 51) and none on filters from the thermocline.

In the reference CTD samples, no MOB were present, except for sporadic Type I MOB cells at the thermocline, where they constituted $<1 \%$ of total DAPI cell counts $(0.01$ $\times 10^{3}$ MOB cells $\mathrm{mL}^{-1}$, Table 3 ).

\section{DGGE and phylogenetic analysis of methanotrophs}

Community fingerprints of Type I MOB and other Gammaproteobacteria from the Blowout crater surface sediments
(BOC 0-1, 1-2 cm and BOW 0-1 cm) were very similar to the one from the bottom-water sample (Fig. 8a). In contrast, the upper water column (thermocline and mixed layer) and waters from the reference CTD were characterized by DGGE band patterns that were distinct from the sediments and the bottom-water sample. However, while the mixed layer sample showed some similarity to the reference CTD sample, the band pattern of the thermocline sample was unique. Phylogenetic analysis of cloned bands (Fig. 8b) revealed that the sequences BW_3 and BOC_3 were identical to a clone from the Haakon Mosby Mud Volcano (HMMVBeg-1; AJ704654; Lösekann et al. 2007). The BW_3/BOC_3 and the BOC_1 sequences grouped into the "Marine Methanotrophic Group I" or "deep sea-clade 1" (Fig. 8b; Ruff et al. 2013; Tavormina et al. 2015). Sequences of BOW_1 and TC_2 also grouped within the Type I MOB, while all other sequences were more closely related to potentially methanotrophrelated clones originating from the water column above cold seeps at the E-Atlantic continental margin (Tavormina et al. 2008). Among these, the sequences of BW_2 and BOC_2 were identical, as were BOC_3 and BW_3.

DGGE band patterns of Type II MOB and other Alphaproteobacteria were similar for both Blowout sediment samples (Fig. 9a). In contrast to the Type I DGGE gels, there was only one strong band in the water-column samples from the bottom water grid and the mixed layer (BW_6, ML_4, respectively) with 


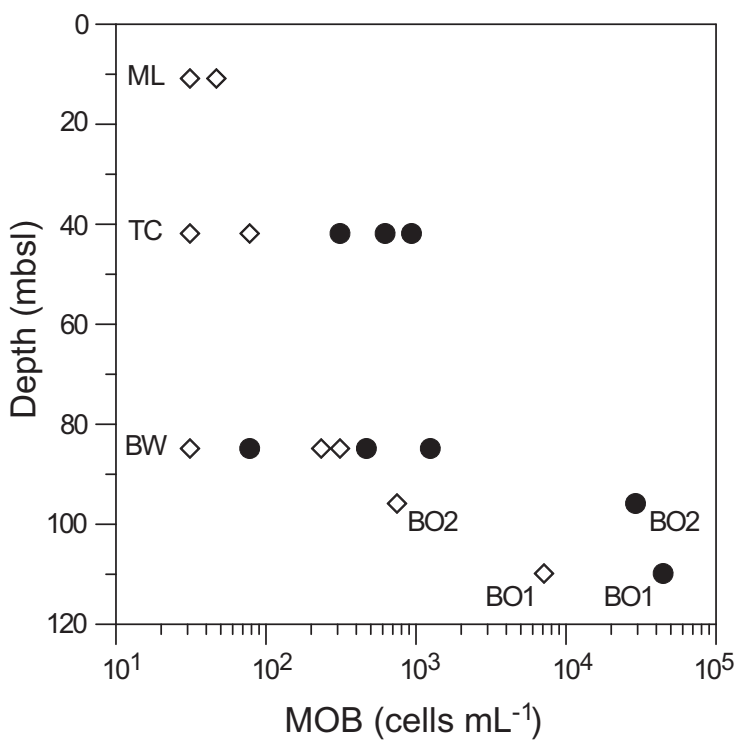

Fig. 7. CARD-FISH cell counts of Type I (open diamonds) and Type II (filled circles) $\mathrm{MOB}$ in the water column. Niskin bottle or CTD cast grids are indicated ( $B W=$ bottom water grid, $T C=$ thermocline, $M L=$ mixed layer). Samples without any detectable Type I or Type II MOB are not shown.

the same migration distance as a band from the sediments (BOC_6). With this exception, the band patterns of watercolumn samples differed from those of the sediment samples. Additionally, the band pattern of all water-column samples did not show a substantial degree of similarity. Sequencing of excised bands and subsequent phylogenetic analyses grouped most sediment and water-column sequences into either the Sphingomonadales or Rhodobacterales clade (Fig. 9b). No sequences were related to the groups conventionally defined as Type II MOB (including only the genus Methylosinus and Methylocystis). However, the sequences from the thermocline (TC_3, TC_4) were closely related to known (obligate) MOB (Methylocapsa sp.) belonging to the family Beijerinckiaceae (Marín and Ruiz Arahal 2014). BOC_5 grouped with uncultivated bacterial clones from gas-hydrate-influenced areas; furthermore, sequences of bands BW_6 and TC_4 showed a relatively high degree of similarity ( $\sim 99 \%)$ when compared to a clone sequence from the water column found in the Gulf of Mexico after the Deepwater Horizon oil spill (S2-8-036; KF786955). The sequences obtained from the faint bands of the bottom water grid (BW_7) and the Blowout sediment sample (BOC_7) were identical, and grouped in the Sphingomonodales clade.

\section{Discussion}

$\mathrm{CH}_{4}$ seepage at the Blowout was triggered as a result of a drilling accident in 1990, during which a shallow gas pocket was tapped. Vigorous seepage mainly in the form of $\mathrm{CH}_{4}$ bubble plumes emanating from the crater's center has been observed during every investigation of the Blowout
(Fox et al. 1995, Rehder et al. 1998, Schneider Von Deimling et al. 2007, Schneider Von Deimling et al. 2015), suggesting uninterrupted seepage since 1990. The Blowout is thus an ideal model system to study the developmental state and activity of $\mathrm{CH}_{4}$-oxidizing communities, as well as the spatial distribution of microbial $\mathrm{CH}_{4}$-oxidation (AOM and MOx) at highly active $\mathrm{CH}_{4}$ point sources in shallow shelf seas.

\section{AOM in sediments}

Two decades after the onset of seepage, our investigations revealed a distinct $A O M$ horizon between 5 and $10 \mathrm{~cm}$ sediment depth at the Blowout crater bottom with ex situ rates that are similar to the highest known AOM activities in the marine environment (e.g., Hydrate Ridge: Boetius et al. 2000; Treude et al. 2003; Black Sea: Treude et al. 2007). Wilfert et al. (2015) found similar (though potential) AOM rates in an in vitro slurry experiment from Blowout crater sediments recovered in 2011. Our ex situ observations thus confirm the development of a highly active AOM community within only two decades after the onset of gas seepage (Wilfert et al. 2015). Despite the highly active AOM community at the Blowout, only a small fraction of $\mathrm{CH}_{4}$ is retained by the sediment $\mathrm{CH}_{4}$ filter, as becomes obvious when considering the high dissolved $\mathrm{CH}_{4}$ concentrations at the sediment water interface and in the water column (Figs. 4, 6; Table 3). The role of SRB in AOM at the Blowout, however, remains unclear. SR and AOM rates displayed similar trends and were of the same order of magnitude, indicating that SR was most likely AOM-dependent (Knittel and Boetius 2009). Yet, we only found large ANME-2 aggregates without any obvious association with SRB (Wilfert et al. 2015), which is rather atypical for sediments characterized by high rates of AOM (Boetius et al. 2000; Michaelis et al. 2002; Niemann et al. 2006). The physical association of ANMEs and SRB, thermodynamic constraints of the AOM reaction (Boetius et al. 2000; Orphan et al. 2001; Treude et al. 2003), and molecular indications for direct electron transfer from ANMEs to SRB (McGlynn et al. 2015) suggests that ANMEs carry out $\mathrm{CH}_{4}$-oxidation with the $\mathrm{SRB}$ as syntrophic partners, where the SRB mediate the reduction of sulfate as the terminal electron acceptor (Knittel and Boetius 2009). On the other hand, a study on an AOM enrichment culture showed that ANMEs may perform complete AOM by themselves (Milucka et al. 2012). Our observations of solitary ANME cells and aggregates supports putative evidence from natural environments that AOM can indeed be performed independent of an obligate SRB partner (see also Orphan et al. 2002; Niemann et al. 2005; Maignien et al. 2013). In contrast to sediments of the Blowout center, the Blowout-wall and background-site sediments were only moderately affected by $\mathrm{CH}_{4}$ bubble emanations and dissolved $\mathrm{CH}_{4}$ seepage (i.e., low $\mathrm{CH}_{4}$ concentrations and low $\mathrm{CH}_{4}$-oxidation rates restricted to the uppermost $\sim 5 \mathrm{~cm}$, Fig. 4), underscoring that $\mathrm{CH}_{4}$ flow is strongly focused within the Blowout crater bottom sediments (Schneider Von Deimling et al. 2015, and references therein). 
a

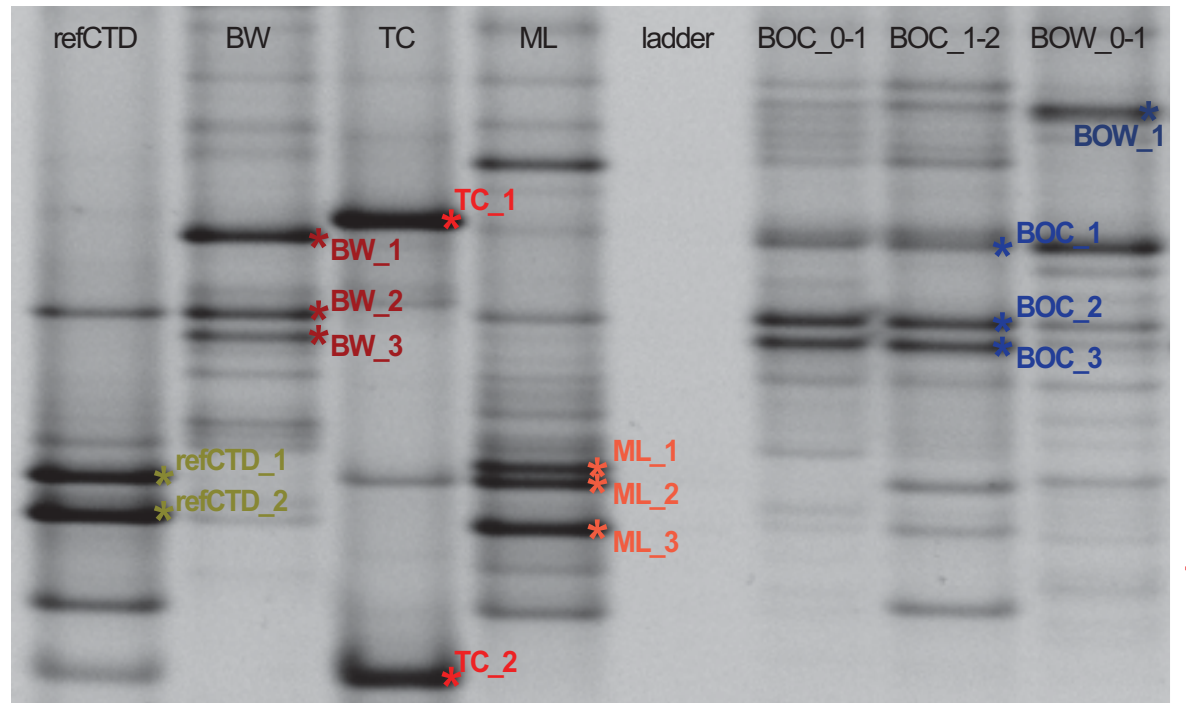

Reference CTD thermocline Bottom Water CTD grid Thermocline CTD grid Mixed Layer CTD grid

Blowout crater sed. $1-2 \mathrm{~cm}$ Blowout wall sed. 0-1 cm

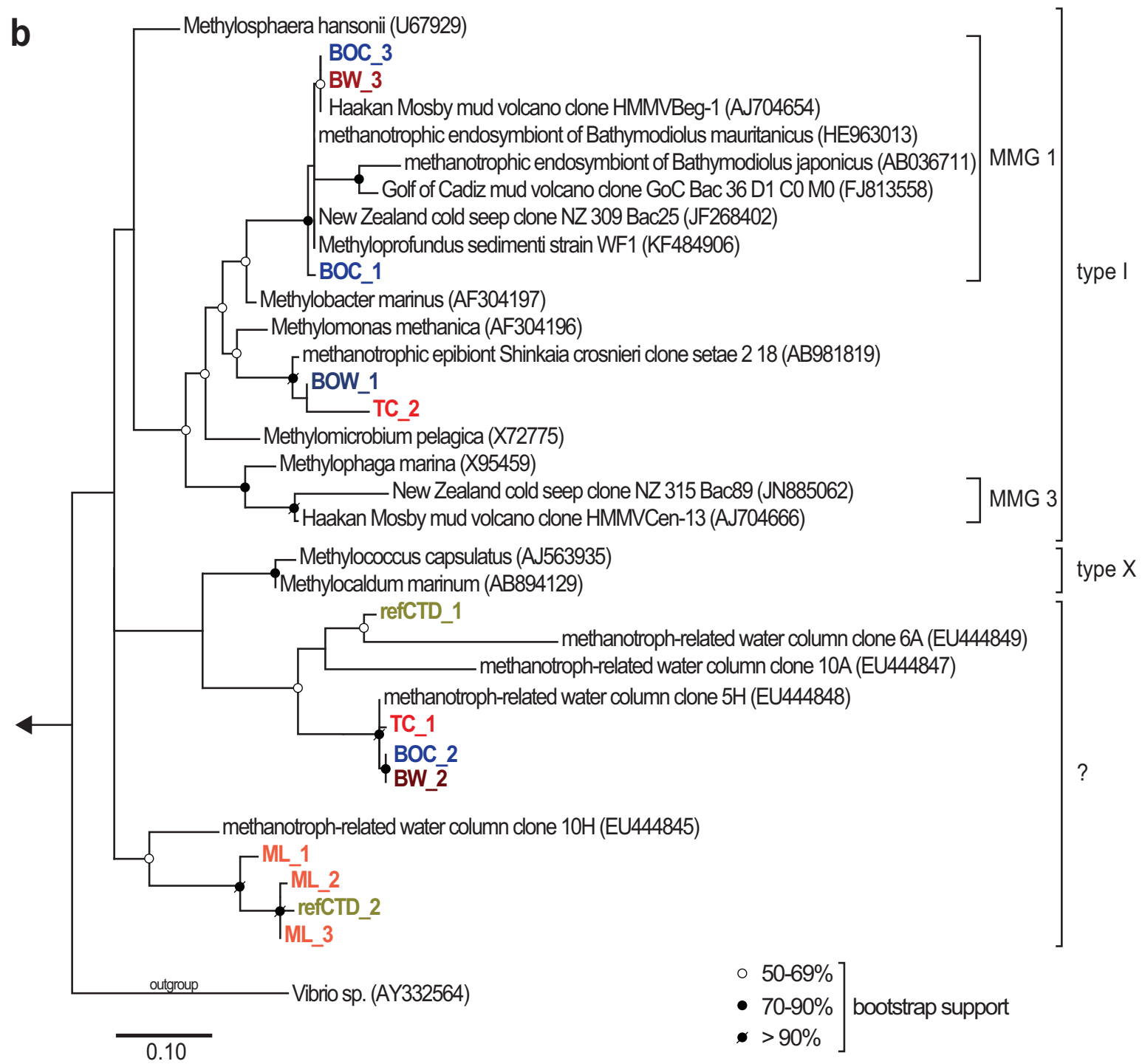

Fig. 8. (a) DGGE community fingerprints of Type I $M O B$ and other Gammaproteobacteria at the different sampling sites. Sample names are indicated ( $\mathrm{BOC}=$ Blowout crater push core, $\mathrm{BOW}=$ Blowout wall push core, $\mathrm{BW}=$ bottom water grid, $\mathrm{TC}=$ thermocline, $\mathrm{ML}=$ mixed layer, refCTD $=$ reference CTD). (b) Maximum likelihood tree based on partial 16S rRNA gene sequences showing the phylogenetic affiliation of sequenced DGGE bands (indicated with a star and a label on the DGGE gels) with closely related cultivated MOB and sequences of uncultivated close relatives from comparable environments. Bootstrap values are based on 2000 sub-samplings. 


\section{Methane oxidation in the water column}

$\mathrm{CH}_{4}$ concentrations in the water column above the Blowout (up to $42 \mu \mathrm{M}$ ) were comparable to other catastrophic $\mathrm{CH}_{4}$-release sites, such as the Deepwater Horizon oil spill site (Kessler et al. 2011; Crespo-Medina et al. 2014), or anoxic marine basins (Reeburgh et al. 1991). Water-column $\mathrm{CH}_{4}$ concentrations at other highly active marine seeps, e.g., at hydrothermal vents at the Juan de Fuca Ridge (deAngelis et al. 1993), cold seeps in the Santa Monica basin (Mau et al. 2012), at Hydrate Ridge (Heeschen et al. 2005), and at the Svalbard continental margin (Steinle et al. 2015), are generally 1-2 orders of magnitude lower. The highest $\mathrm{CH}_{4}$ concentrations at the Blowout (i.e., $\left[\mathrm{CH}_{4}\right]>5000 \mathrm{nM}$, Fig. 6b,c) seem to be constrained to waters most directly influenced by the main bubble plume (Schneider Von Deimling et al. 2015; Sommer et al. 2015). The horizontal extension of the plume can be estimated from the highest $\mathrm{CH}_{4}$ concentrations located in the eastern part of the CTD grid (Fig. 6b,c). In line with results from data from 2011 (Sommer et al. 2015), bottom water grid samples (Fig. 6c) showed ubiquitously high $\mathrm{CH}_{4}$ concentrations $(\sim 900 \mathrm{nM})$, and thus a strong lateral influence of the plume, possibly driven by density-driven recirculation of $\mathrm{CH}_{4}$-rich waters ascending with the main bubble plume (Schneider Von Deimling et al. 2015, Wilson et al. 2015). At the thermocline, the impact of the bubble plume on $\mathrm{CH}_{4}$-concentrations seems reduced and less constant $\left(\mathrm{CH}_{4}\right.$-concentrations as low as $50 \mathrm{nM}$; Fig. 6b). See Sommer et al. (2015) and Schneider Von Deimling et al. (2015) for a detailed discussion on lateral plume extension.

At the Blowout, $>95 \%$ of the uprising $\mathrm{CH}_{4}$ seems to be trapped below the thermocline (Schneider Von Deimling et al. 2007; Sommer et al. 2015), so that relatively little $\mathrm{CH}_{4}$ reaches the mixed layer (see Fig. 6a). Yet, the fate of the uprising $\mathrm{CH}_{4}$ is not completely certain. The enrichment of ${ }^{13} \mathrm{C}$ of thermocline $\mathrm{CH}_{4}$ relative to the source $\mathrm{CH}_{4}$ (Table 3; Fig. 4d-f) is consistent with C-isotope fractionation during partial $\mathrm{CH}_{4}$-consumption by $\mathrm{MOx}$ (Whiticar 1999) and implies that a fraction of seep-derived $\mathrm{CH}_{4}$ is oxidized in the water column. However, the rather subtle increase in $\delta^{13} \mathrm{C}$ suggests that ${ }^{13} \mathrm{C}$-enrichment during MOx is counteracted by the continuous resupply of $\mathrm{CH}_{4}$ with a low $\delta^{13} \mathrm{C}$-signature. In light of the very high water-column $\mathrm{CH}_{4}$ concentrations, mixing with atmospheric $\mathrm{CH}_{4}$ (about $-47 \%$; NOAA-ESRL network) can be excluded to cause the observed ${ }^{13} \mathrm{C}$-isotopic enrichment in the residual $\mathrm{CH}_{4}$ pool, leaving partial consumption by water-column MOx as the most likely explanation for the elevated methane $\delta^{13} \mathrm{C}$ within the thermocline.

The MOx rates in the Blowout water column (Figs. 3b, $6 g-i)$ are among the highest values reported for marine environments (Reeburgh 2007; Mau et al. 2013; Steinle et al. 2015). They lie within the same range as rates detected in the anoxic basin of the Black Sea (Reeburgh et al. 1991) and the Gulf of Mexico water column following the Deepwater Horizon oil spill (Kessler et al. 2011; Crespo-Medina et al.
2014). Two rate maxima were observed within the water column, one within the crater and the second one at the thermocline (Fig. 3b), indicating more favorable conditions for MOx in these water layers. Previous studies found that important factors controlling $\mathrm{MOx}$ are (1) $\mathrm{CH}_{4}$ availability, (2) trace metal abundance, and/or (3) changes in the abundance of MOB bacteria caused by water mass exchange (Semrau et al. 2010; Kessler et al. 2011; Mau et al. 2013; Crespo-Medina et al. 2014; Steinle et al. 2015).

1. $\mathrm{CH}_{4}$ availability. Low $\mathrm{CH}_{4}$ concentrations may explain the overall low MOx rates in the mixed layer; and the high variability of MOx rates in the thermocline may to some extent be related to variable $\mathrm{CH}_{4}$ concentrations (Fig. 6). However, even though very high $\mathrm{CH}_{4}$ concentrations were observed both in the bottom water grid and in crater waters, MOx rates were much lower in the bottom water grid compared to crater waters. The overall rather poor correlation between $\mathrm{CH}_{4}$ concentrations and $\mathrm{MOx}$ ( $R^{2}$-values $<0.2$; data not shown) implies that the ambient $\mathrm{CH}_{4}$ concentrations are not the major control on $\mathrm{MOx}$ activity in these water layers.

2. Trace metal abundance. No water-column trace metal data are available for the Blowout area. However, within the crater and the plume above, it seems plausible that sediment mobilization can increase the concentration of trace metals that are important for MOB (i.e., $\mathrm{Cu}, \mathrm{Fe}$; Semrau et al. 2010) and thus stimulate MOx in the water column (see section below "Type II methanotrophs in the water column" for further discussion).

3. Water mass transport. The space within the Blowout crater is partly shielded against tidal influences/currents, providing relatively stable conditions. We also detected a constant supply of MOB from surface sediments to the water column within the crater (see section below "Sediment-borne MOB fuel the water-column MOx filter"). Combined, these factors appear to warrant conditions conducive to MOB community development and thus high MOx rates (Steinle et al. 2015). A similar situation seems to apply to thermocline waters, where $\mathrm{CH}_{4}$ is being trapped during density stratification. Yet, the rather variable $\mathrm{CH}_{4}$ concentrations (Fig. 6b) suggest a stronger influence by lateral advection (Sommer et al. 2015). At seeps offshore Svalbard, lateral transport of water-column MOB away from the $\mathrm{CH}_{4}$ point source was found to reduce water-column MOx activity (Steinle et al. 2015). In comparison to the crater, the more variable conditions at the Blowout's thermocline may thus explain the fluctuating MOx rates in this water layer (Fig. 6h).

\section{Sediment-borne MOB fuel the water-column MOx filter}

Sediment particles on the filter from the Blowout crater water sample (Fig. 5i) and, though less abundant, on filters from the bottom water grid (Fig. 5l) indicate that sediment 
is entrained in the bubble plume and transported into the water column. Our DGGE and phylogenetic analysis revealed several bottom water sequences (BW_2, BW_3, BW_7), which were identical to sequences from crater surface sediments (BOC_2, BOC_3, BOC_7; Figs. 8, 9) providing evidence that mobilized sediments provide a vector for transporting benthic microbes into the water column. The distribution of sediment particles in the water column paired with the identity of pelagic vs. benthic microbes thus suggests that MOB, maybe in immediate association with sediment particles, were transported at least $\sim 40 \mathrm{~m}$ up into the water column. The elevated MOx rates in the bottom water grid samples are likely supported by the ebullition-aided dispersal of sediment-borne MOB, which seem to continuously re-stock the MOx filter in the water column. A recent study by Schmale et al. (2015) described the entrainment of MOB by bubbles at the Rostocker seep site (Coal Oil Point seep field, California) as "bubble transport mechanism"; however, the bubble stream with the entrained microbes was captured only $15 \mathrm{~cm}$ above the sediment surface. Here, we confirm that mobilization of sediment microbes into the water column can play an important role for inoculating the water column. In addition, we demonstrate for the first time that "bubble plumes" can transport microbes over much larger vertical distances, thereby linking benthic and pelagic bacterial communities. Although other work at cold seeps could not find similar MOB communities in sediments and in bottom waters (Tavormina et al. 2008), our study suggests that transport of benthic microbes far into the water column may be a globally important mechanism that shapes the regional microbial biogeography (Schmale et al. 2015).

\section{Type II methanotrophs in the water column}

Results from earlier studies suggest that aerobic MOB in marine habits almost exclusively belong to Type I MOB (Elsaied et al. 2004; Tavormina et al. 2013, 2010; Reed et al. 2009; Kessler et al. 2011; Håvelsrud et al. 2011, Steinle et al. 2015). In some marine studies, Type II MOB were observed, but in all cases they constituted only a small part of the methanotrophic community (Wang et al. 2004; McDonald et al. 2005; Hamdan et al. 2011). So far, Type II-dominated MOB communities seem to be restricted to certain freshwater systems, e.g., some arctic lakes (He et al. 2012), soils (Henckel et al. 2000), and rice fields (Bodelier et al. 2000; Macalady et al. 2002). Our finding of a Type II-dominated MOB community in the water column at the Blowout (Fig. 9) is thus unique. The recruitment from the sediments (where both Type I and II MOB were detected, Table 3; Fig. 5 ) provides a stock of both types of aerobic MOB to bottom waters, which explains the presence of Type II MOB in the bottom water grid. However, it remains unclear as to why the thermocline MOB community at the Blowout is dominated by Type II MOB. Very little is known about factors selecting for this group of MOB. Hanson and Hanson (1996) suggested that Type II MOB are better adapted to high $\mathrm{CH}_{4}$ concentrations, which agrees with more recent environmental observations (Bodelier et al. 2000; Henckel et al. 2000; Macalady et al. 2002; Kessler et al. 2011; He et al. 2012). Besides $\mathrm{CH}_{4}$ concentrations, the availability of copper and iron (which are present in the reaction centers of the soluble and particulate MMO, respectively) may also influence expression, enzyme activity, and ultimately the community structure of MOB. For example, pMMO has been found to be less expressed under copper limitation compared to sMMO (Murrell 2010). While Type II MOB often have the ability to express both, pMMO and sMMO, most Type I MOB synthesize only the particulate form of MMO (Semrau et al. 2010, and references therein). We did not measure water-column trace metal concentrations, so that we can only speculate whether the water column at the Blowout is depleted in copper, which could potentially limit the expression of pMMO and thus give competitive advantage to Type II MOB over Type I MOB. We propose that elevated levels of $\mathrm{CH}_{4}$ in the water column paired with potential copper limitation (to be confirmed by future work) constitute important selection mechanisms for Type II MOB at the Blowout.

\section{Diversity of MOB in the blowout area}

Phylogenetic analyses revealed strong differences between the MOB and phylogenetically related communities in the bottom water grid, the thermocline, and the mixed layer. As for Type I MOB, we found several sequences from the bottom water grid (and from the Blowout crater sediment) that were closely related to known MOB of the "Marine Methanotrophic Group I" or "deep-sea clade 1." These sequences are thus originating from obligate MOB (Tavormina et al. 2008; Ruff et al. 2013). Similarly, two sequences from the bottom water grid and the thermocline at the Blowout are also likely to originate from bacteria mediating MOx, since they were closely related to a methanotrophic epibiont from a deep-sea crab (Watsuji et al. 2014). In addition to sequences related to known obligate $\mathrm{MOB}$, we found several sequences that were closely related to putatively methanotroph-related bacteria previously found in the water column at cold seeps off the US West Coast (Tavormina et al. 2008). Their occurrence at the Blowout, and at two other $\mathrm{CH}_{4}$-rich environments (Eel River Basin and Santa Monica Basin; Tavormina et al. 2008) may indicate an involvement of these organisms in hydrocarbon degradation.

The Type II MOB recovered from the water column belong to the order Rhizobiales within the class Alphaproteobacteria and, therein, to two genera of the family Methylocystacea: Methylocystis or Methylosinus. Two additional genera, Methylocella and Methylocapsa within the order Rhizobiales, were recently identified as obligate methanotrophs, but are not considered traditional Type II MOB as they belong to the family Beijerinckiacea and not to Methylocystacea (Marín and Ruiz Arahal 2014). The identified sequences from the 
a
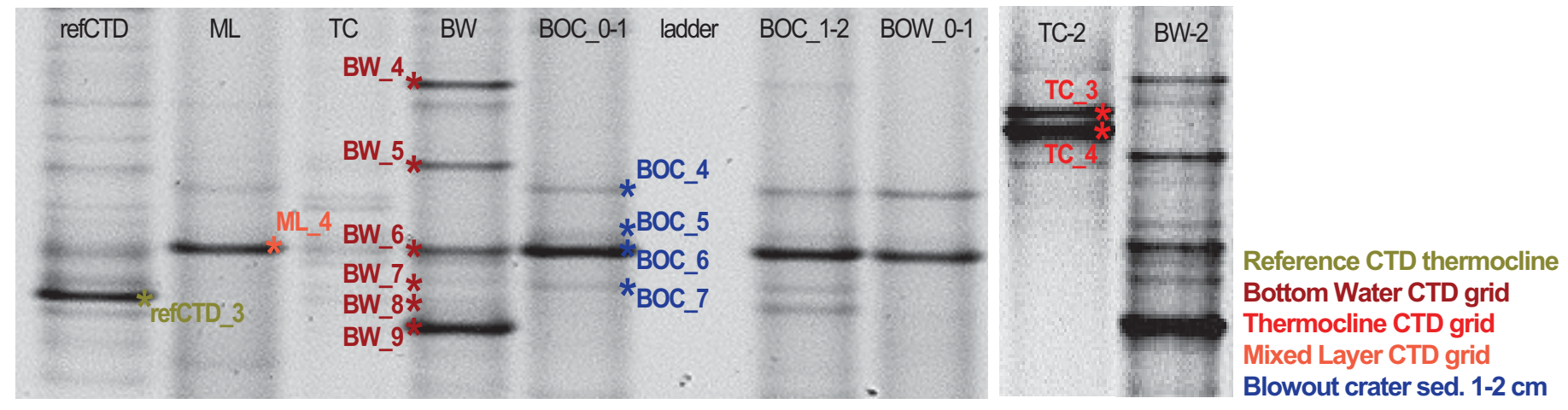

b

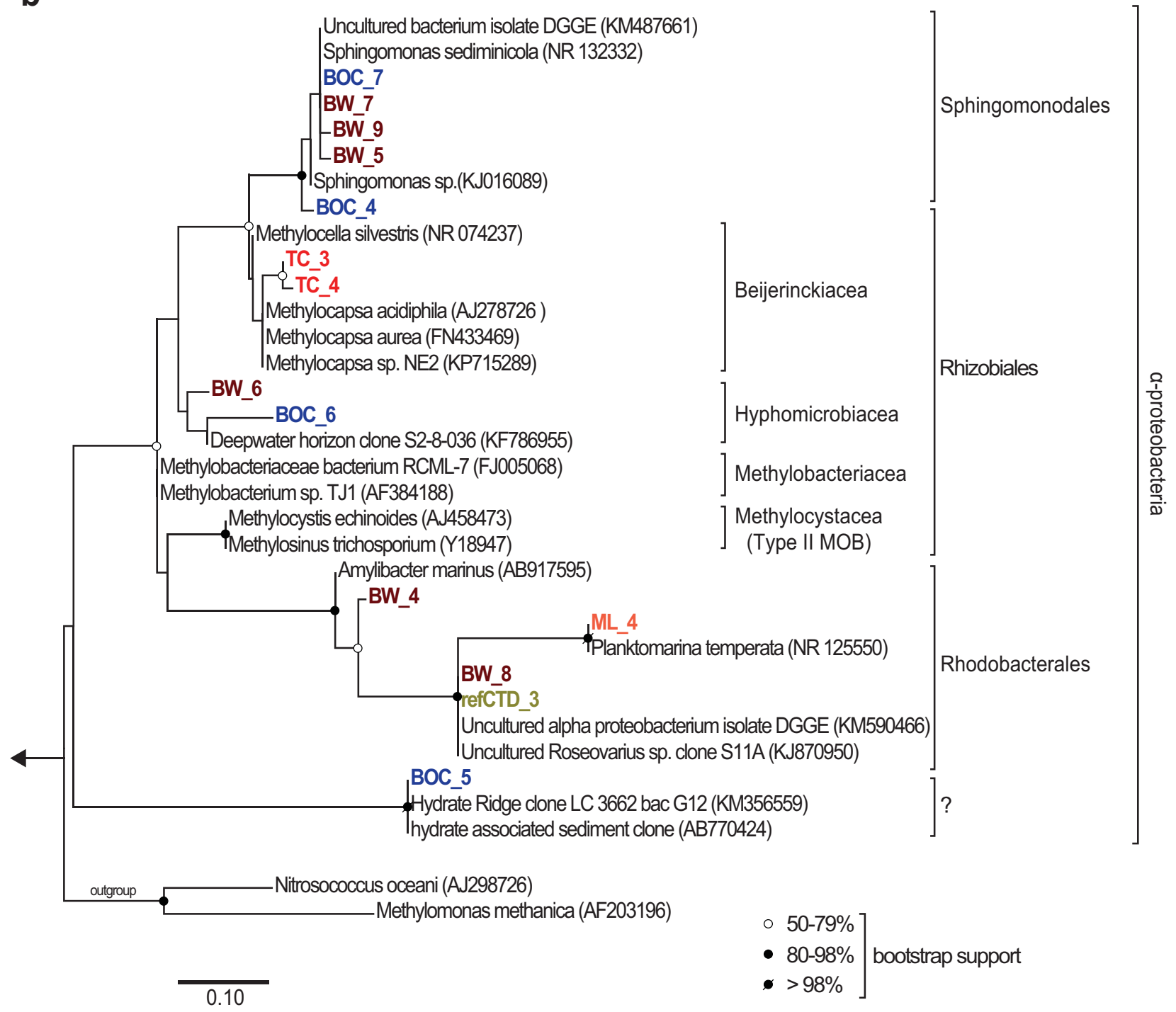

Fig. 9. (a) DGGE community fingerprints of Type II $M O B$ and other Alphaproteobacteria at the different sampling sites. Sample names are indicated $(\mathrm{BOC}=$ Blowout crater push core, $\mathrm{BOW}=$ Blowout wall push core, $\mathrm{BW}=$ bottom water grid, $\mathrm{TC}=$ thermocline, $\mathrm{ML}=$ mixed layer, refCTD $=$ reference CTD). The bands for the thermocline sample (TC_3, TC_4) are from a second DGGE-gel. (b) Maximum likelihood tree based on partial 16S rRNA gene sequences showing the phylogenetic affiliation of sequenced DGGE bands (indicated with a star and a label on the DGGE gels) with closely related cultivated $\mathrm{MOB}$ and sequences of uncultivated close relatives from comparable environments. Bootstrap values are based on 2000 sub-samplings. 
thermocline are closely related to Methylocapsa sp. (TC_3 and TC_4) are hence most likely (obligate) methanotrophs. Several other Rhizobiales members, belonging to the Methylobacteriaceae and Hyphomicrobiacea, were found to be methylotrophic (e.g., Urakami et al. 1995; Vuilleumier et al. 2011; Marx et al. 2012). As a result, the sequences from the BW grid and the Blowout crater sediments (BW_6, BOC_6) clustering with Hyphomicrobium sp. and with a clone sequence recovered from the water column after the Deepwater Horizon oil spill (KF786955) could also be involved in hydrocarbon degradation. Similarly, another crater sediment sequence (BOC_2) is closely related to environmental clones from hydrate-influenced areas and an involvement in $\mathrm{CH}_{4}$ metabolism is hence possible.

\section{Efficiency of the water-column methane filter}

At the Blowout, less than 5\% of the uprising dissolved $\mathrm{CH}_{4}$ is estimated to reach the upper mixed layer during stratified conditions (Schneider Von Deimling et al. 2015; Sommer et al. 2015). The thermocline acts as a barrier, which delays diffusive $\mathrm{CH}_{4}$ emissions into the atmosphere and, thus, enhances the $\mathrm{CH}_{4}$ availability for water-column MOB communities. For the water column where the $\mathrm{CH}_{4}$ is trapped (i.e., below the upper mixed layer: 20-98 mbsl), we calculated a depth-weighted average turnover constant $(k)$ by linear interpolation between the measured $k$ in the thermocline, the bottom water grid and in bottom waters sampled $0.5 \mathrm{~m}$ above the seafloor (BO2). The depth-weighted $k$ was 0.01-0.03 $\mathrm{d}^{-1}$ when considering average and maximum $k$ in the different water layers, respectively (Table 3 ). This translates to a $\mathrm{CH}_{4}$ turnover time $(1 / k)$, of 92 or 31 days for average and maximum depth-weighted $k$ values, respectively. Assuming that first-order rate kinetics apply, MOx has the potential to oxidize only $1-3 \%$ of the $\mathrm{CH}_{4}$ in our study area. The only possible sink for the remaining $>95 \%$ of the emitted $\mathrm{CH}_{4}$ is lateral advective transport away from the immediate Blowout-seep area. Strong tidal currents will not only transport $\mathrm{CH}_{4}$ (Sommer et al. 2015) laterally away from the $\mathrm{CH}_{4}$ point source, but probably also MOB (Steinle et al. 2015), so that MOx is very likely to proceed outside the immediate Blowout seep area. Indeed, previous work from the Svalbard Continental margin suggests that much of the total $\mathrm{CH}_{4}$ liberated from a cold seep area is likely consumed downstream of the $\mathrm{CH}_{4}$ point source (Graves et al. 2015; Steinle et al. 2015). The efficiency of the water-column MOx thus depends strongly on the time scale of turbulent vertical mixing, i.e., the time needed for $\left(\mathrm{CH}_{4}\right.$-rich) water to be transported from the sea floor to the sea surface in a MOBcontaining water parcel. In the Blowout region, slow vertical mixing during stratified conditions results in a retention time for $\mathrm{CH}_{4}$ of $\sim 23$ days (Nauw et al. 2015). Assuming that the range of depth-weighted $k$ values determined above also apply to MOx during lateral transport of the MOB community away from the Blowout, and given typical vertical mixing rates under stratified conditions, we calculate that at least $25 \%$ (and up to $74 \%$ ) of the emitted $\mathrm{CH}_{4}$ could be oxidized. Importantly, our estimates do not consider that advectionrelated dilution of the MOB cell density may act to lower $k$. On the other hand, these estimates also do not take into account the possibility of MOB community growth during lateral transport away from the Blowout, which would likely lead to higher $k$ values.

During fully mixed conditions, in contrast, rapid vertical transport within the water column leads to a short retention time for $\mathrm{CH}_{4}$ of $\sim 1$ day (Nauw et al. 2015). Even a similarly active MOB community as the one present during stratified conditions could thus only consume $<3 \%$ of the emitted $\mathrm{CH}_{4}$. Yet, the development of a highly active MOB community is unlikely under fully mixed conditions due to a lack of environmental stability and continuity (Steinle et al. 2015), resulting in an even less efficient $\mathrm{CH}_{4}$ removal. Additional investigations of MOx activity in the water column in the wider Blowout area under both stratified and fully mixed conditions are necessary to further constrain the fate of the seep-derived $\mathrm{CH}_{4}$ and the overall MOx filter capacity.

In conclusion, $\mathrm{MOx}$ rates in the water column at the Blowout are among the highest rates ever measured in a marine environment, and effectively consume a significant part of the emitted $\mathrm{CH}_{4}$, at least during stratified conditions. We speculate, however, that the microbial methane filter is temporarily suspended during fully mixed conditions. The MOB community in the lower water column is (at least in parts) recruited from sedimentary $\mathrm{MOB}$, which are entrained in $\mathrm{CH}_{4}$-bubble plumes rising from the sediments and transported into the water column. Hence our study demonstrates that gas ebullition not only provides ample $\mathrm{CH}_{4}$ substrate fueling MOx in the water column, it also serves as an important vector for sediment-borne microbial inocula that aid in the establishment of a water-column methanotrophic community at high-flux cold seeps.

\section{References}

Berndt, C., and others. 2014. Temporal constraints on hydrate-controlled methane seepage off Svalbard. Science 343: 284-287. doi:10.1126/science. 1246298

Biastoch, A., and others. 2011. Rising Arctic Ocean temperatures cause gas hydrate destabilization and ocean acidification. Geophys. Res. Lett. 38: L08602. doi:10.1029/ 2011GL047222

Blees, J., and others. 2014. Micro-aerobic bacterial methane oxidation in the chemocline and anoxic water column of deep south-Alpine Lake Lugano (Switzerland). Limnol. Oceanogr. 59: 311-324. doi:10.4319/lo.2014.59.2.0311

Bodelier, P. L., P. Roslev, T. Henckel, and P. Frenzel. 2000. Stimulation by ammonium-based fertilizers of methane oxidation in soil around rice roots. Nature 403: 421-424. doi:10.1038/35000193 
Boetius, A., and others. 2000. A marine microbial consortium apparently mediating anaerobic oxidation of methane. Nature 407: 623-626. doi:10.1038/35036572

Boetius, A., and F. Wenzhöfer. 2013. Seafloor oxygen consumption fuelled by methane from cold seeps. Nat. Geosci. 6: 725-734. doi:10.1038/ngeo1926

Costello, A. M., and M. E. Lidstrom. 1999. Molecular characterization of functional and phylogenetic genes from natural populations of methanotrophs in lake sediments. Appl. Environ. Microb. 65: 5066-5074.

Crespo-Medina, M., and others. 2014. The rise and fall of methanotrophy following a deepwater oil-well blowout. Nat. Geosci. 7: 423-427. doi:10.1038/ngeo2156

deAngelis, M. A., M. D. Lilley, and J. A. Baross. 1993. Methane oxidation in deep-sea hydrothermal plumes of the endeavour segment of the Juan de Fuca Ridge. Deep-Sea Res. Part I. 40: 1169-1186. doi:10.1016/0967-0637(93)90132-M

Eller, G., S. Stubner, and P. Frenzel. 2001. Group-specific 16S rRNA targeted probes for the detection of type I and type II methanotrophs by fluorescence in situ hybridisation. FEMS Microbiol. Lett. 198: 91-97. doi:10.1111/j.15746968.2001.tb10624.x

Elsaied, H. E., T. Hayashi, and T. Naganuma. 2004. Molecular analysis of deep-sea hydrothermal vent aerobic methanotrophs by targeting genes of $16 \mathrm{~S}$ rRNA and particulate methane monooxygenase. Mar. Biotechnol. 6: 503-509. doi:10.1007/s10126-004-3042-0

Ferré, B., J. Mienert, and T. Feseker. 2012. Ocean temperature variability for the past 60 years on the NorwegianSvalbard margin influences gas hydrate stability on human time scales. J. Geophys. Res. 117: C10017. doi: 10.1029/2012JC008300

Fox, M. A. 1995. Memoradum 22/4b-4 well site hazards. MOBIL North Sea Ltd.

Grasshoff, K., K. Kremling, and M. Ehrhardt. 1999. Methods of seawater analysis. Wiley.

Graves, C. A., and others. 2015. Fluxes and fate of dissolved methane released at the seafloor at the landward limit of the gas hydrate stability zone offshore western Svalbard. J. Geophys. Res. Oceans 120: 6185-6201. doi:10.1002/ 2015JC011084

Haffert, L., and others. 2013. Fluid evolution and authigenic mineral paragenesis related to salt diapirism-the Mercator mud volcano in the Gulf of Cadiz. Geochim. Cosmochim. Acta 106: 261-286. doi:10.1016/j.gca.2012. 12.016

Hamdan, L. J., P. M. Gillevet, J. W. Pohlman, M. Sikaroodi, J. Greinert, and R. B. Coffin. 2011. Diversity and biogeochemical structuring of bacterial communities across the Porangahau ridge accretionary prism, New Zealand. FEMS Microbiol. Ecol. 77: 518-532. doi:10.1111/j.1574-6941. 2011.01133.x

Hanson, R. S., and T. E. Hanson. 1996. Methanotrophic bacteria. Microbiol. Rev. 60: 439-471.
Håvelsrud, O., T. H. Haverkamp, T. Kristensen, K. S. Jakobsen, and A. Rike. 2011. A metagenomic study of methanotrophic microorganisms in Coal Oil Point seep sediments. BMC Microbiol. 11: 221. doi:10.1186/14712180-11-221

He, R., M. J. Wooller, J. W. Pohlman, J. Quensen, J. M. Tiedje, and M. B. Leigh. 2012. Shifts in identity and activity of methanotrophs in arctic lake sediments in response to temperature changes. Appl. Environ. Microbiol. 78: 4715-4723. doi:10.1128/AEM.00853-12

Heeschen, K. U., R. W. Collier, M. A. de Angelis, E. Suess, G. Rehder, P. Linke, and G. P. Klinkhammer. 2005. Methane sources, distributions, and fluxes from cold vent sites at Hydrate Ridge, Cascadia Margin. Global Biogeochem. Cycle 19: GB2016. doi:10.1029/2004GB002266

Henckel, T., P. Roslev, and R. Conrad. 2000. Effects of $\mathrm{O}_{2}$ and $\mathrm{CH}_{4}$ on presence and activity of the indigenous methanotrophic community in rice field soil. Environ. Microbiol. 2: 666-679. doi:10.1046/j.1462-2920.2000.00149.x

IPCC. 2013. Climate Change 2013: The Physical Science Basis. Contribution of Working Group I to the Fifth Assessment Report of the Intergovernmental Panel on Climate Change. In T. F. Stocker and others [eds.], Cambridge Univ. Press. doi:10.1017/CBO9781107415324

James, R. H., and others. 2016. Effects of climate change on methane emissions from seafloor sediments in the Arctic Ocean: A review. Limnol. Oceanogr. doi:10.1002/ lno.10307.

Jørgensen, B. B. 1977. The sulfur cycle of a coastal marine sediment (Limfjorden, Denmark). Limnol. Oceanogr. 22: 814-832. doi:10.4319/1o.1977.22.5.0814

Jørgensen, B. B., and T. Fenchel. 1974. The sulfur cycle of a marine sediment model system. Mar. Biol. 24: 189-201. doi:10.1007/BF00391893

Judd, A. 2015. The significance of the $22 / 4$ b blow-out site methane emissions in the context of the North Sea. Mar. Pet. Geol. 68: 836-847. doi:10.1016/j.marpetgeo. 2015.07.031

Judd, A., and M. Hovland. 2007. Seabed fluid flow: The impact of geology, biology and the marine environment. Cambridge Univ. Press.

Kallmeyer, J., T. G. Ferdelman, A. Weber, H. Fossing, and B. B. Jørgensen. 2004. A cold chromium distillation procedure for radiolabeled sulfide applied to sulfate reduction measurements. Limnol. Oceanogr. Methods 2: 171-180. doi:10.4319/lom.2004.2.171

Kessler, J. D., and others. 2011. A persistent oxygen anomaly reveals the fate of spilled methane in the deep Gulf of Mexico. Science 331: 312-315. doi:10.1126/science. 1199697

Kimura, M. 1980. A simple method for estimating evolutionary rates of base substitutions through comparative studies of nucleotide sequences. J. Mol. Evol. 16: 111-120. doi:10.1007/BF01731581 
Kirschke, S., and others. 2013. Three decades of global methane sources and sinks. Nat. Geosci. 6: 813-823. doi: 10.1038/ngeo1955

Knittel, K., and A. Boetius. 2009. Anaerobic oxidation of methane: Progress with an unknown process. Annu. Rev. Microbiol. 63: 311-334. doi:10.1146/annurev.micro.61. 080706.093130

Lane, D. J. 1991. 16S/23S rRNA sequencing, p. 125-175. In E. Stackebrandt and M. Goodfellow [eds.], Nucleic acid techniques in bacterial systematics. Wiley.

Leifer, I., and A. Judd. 2015. The UK22/4b blowout 20 years on: Investigations of continuing methane emissions from sub-seabed to the atmosphere in a North Sea context. Mar. Pet. Geol. 68: 706-717. doi:10.1016/j.marpetgeo. 2015.11.012

Linke, P. 2012. RV Celtic Explorer EUROFLEETS cruise report CE12010-ECO2, NorthSea: 20.07.-06.08. 2012, BremerhavenHamburg. GEOMAR Report, N. Ser. 004.

Linke, P., M. Schmidt, M. Rohleder, A. Al-Barakati, and R. Al-Farawati. 2015. Novel online digital video and highspeed data broadcasting via standard coaxial cable onboard marine operating vessels. Mar. Technol. Soc. J. 49: 7-18. doi:10.4031/MTSJ.49.1.2

Lösekann, T., K. Knittel, T. Nadalig, B. Fuchs, H. Niemann, A. Boetius, and R. Amann. 2007. Diversity and abundance of aerobic and anaerobic methane oxidizers at the Haakon Mosby mud volcano, Barents Sea. Appl. Environ. Microbiol. 73: 3348-3362. doi:10.1128/AEM.00016-07

Macalady, J. L., A. M. S. McMillan, A. F. Dickens, S. C. Tyler, and K. M. Scow. 2002. Population dynamics of type I and II methanotrophic bacteria in rice soils. Environ. Microbiol. 4: 148-157. doi:10.1046/j.1462-2920.2002.00278.x

Maignien, L., R. J. Parkes, B. Cragg, H. Niemann, K. Knittel, S. Coulon, A. Akhmetzhanov, and N. Boon. 2013. Anaerobic oxidation of methane in hypersaline cold seep sediments. FEMS Microbiol. Ecol. 83: 214-231. doi:10.1111/ j.1574-6941.2012.01466.X

Marín, I., and D. Ruiz Arahal. 2014. The family Beijerinckiaceae, p. 263-282. In E. Rosenberg, E. F. DeLong, S. Lory, E. Stackebrandt, and F. Thompson [eds.], The prokaryotes. Springer.

Marx, C. J., and others. 2012. Complete genome sequences of six strains of the genus Methylobacterium. J. Bacteriol. 194: 4746-4748. doi:10.1128/JB.01009-12

Mau, S., M. B. Heintz, and D. L. Valentine. 2012. Quantification of $\mathrm{CH}_{4}$ loss and transport in dissolved plumes of the Santa Barbara Channel, California. Cont. Shelf Res. 32: 110-120. doi:10.1016/j.csr.2011.10.016

Mau, S., J. Blees, E. Helmke, H. Niemann, and E. Damm. 2013. Vertical distribution of methane oxidation and methanotrophic response to elevated methane concentrations in stratified waters of the Arctic fjord Storfjorden (Svalbard, Norway). Biogeosciences 10: 6267-6278. doi: 10.5194/bg-10-6267-2013
McDonald, I. R., K. Smith, and M. E. Lidstrom. 2005. Methanotrophic populations in estuarine sediment from Newport Bay, California. FEMS Microbiol. Lett. 250: 287-293. doi:10.1016/j.femsle.2005.07.016

McGlynn, S. E., G. L. Chadwick, C. P. Kempes, and V. J. Orphan. 2015. Single cell activity reveals direct electron transfer in methanotrophic consortia. Nature 526: 531535. doi:10.1038/nature 15512

Michaelis, W., and others. 2002. Microbial reefs in the Black Sea fueled by anaerobic oxidation of methane. Science 297: 1013-1015. doi:10.1126/science.1072502

Milucka, J., and others. 2012. Zero-valent sulphur is a key intermediate in marine methane oxidation. Nature 491: 541-546. doi:10.1038/nature11656

Murray, A. E., J. T. Hollibaugh, and C. Orrego. 1996. Phylogenetic compositions of bacterioplankton from two California estuaries compared by denaturing gradient gel electrophoresis of $16 \mathrm{~S}$ rDNA fragments. Appl. Environ. Microbiol. 62: 2676-2680.

Murrell, J. C. 2010. The aerobic methane oxidizing bacteria (methanotrophs), p. 1953-1966. In K. N. Timmis [eds.], Handbook of hydrocarbon and lipid microbiology. Springer.

Nauw, J., H. D. Haas, and G. Rehder. 2015. A review of oceanographic and meteorological controls on the North Sea circulation and hydrodynamics with a view to the fate of North Sea methane from well site 22/4b and other seabed sources. Mar. Pet. Geol. 68: 861-882. doi:10.1016/ j.marpetgeo.2015.08.007

Niemann, H., and others. 2005. Methane emission and consumption at a North Sea gas seep (Tommeliten area). Biogeosciences 2: 335-351. doi:10.5194/bg-2-335-2005

Niemann, H., and others. 2006. Novel microbial communities of the Haakon Mosby mud volcano and their role as a methane sink. Nature 443: 854-858. doi:10.1038/ nature05227

Niemann, H., and others. 2009. Biogeochemistry of a lowactivity seep in the Larsen B area, western Weddell Sea, Antarctica. Biogeosciences 6: 2383-2395. doi:10.5194/bg6-2383-2009

Niemann, H., L. I. Steinle, J. Blees, S. Krause, I. Bussmann, T. Treude, M. Elvert, and M. F. Lehmann. 2015. Toxic effects of butyl elastomers on aerobic methane oxidation. Limnol. Oceanogr. Methods 13: 40-52. doi:10.1002/lom3. 10005

Orphan, V. J., C. H. House, K. U. H. Hinrichs, K. D. McKeegan, and E. F. Delong. 2001. Methane-consuming archaea revealed by directly coupled isotopic and phylogenetic analysis. Science 293: 484-487. doi:10.1126/ science. 1061338

Orphan, V. J., C. H. House, K. U. Hinrichs, K. D. McKeegan, and E. F. DeLong. 2002. Multiple archaeal groups mediate methane oxidation in anoxic cold seep sediments. Proc. Natl. Acad. Sci. U. S. A. 99: 7663-7668. doi:10.1073/pnas. 072210299 
Pernthaler, A., J. Pernthaler, and R. Amann. 2002. Fluorescence in situ hybridization and catalyzed reporter deposition for the identification of marine bacteria. Appl. Environ. Microbiol. 68: 3094-3101. doi:10.1128/AEM. 68.6.3094-3101.2002

Pruesse, E., J. Peplies, and F. O. Glockner. 2012. SINA: Accurate high-throughput multiple sequence alignment of ribosomal RNA genes. Bioinformatics 28: 1823-1829. doi: 10.1093/bioinformatics/bts252

Queste, B. Y., L. Fernand, T. D. Jickells, K. J. Heywood, and A. J. Hind. 2016. Drivers of summer oxygen depletion in the central North Sea. Biogeosciences 13: 1209-1222. doi: 10.5194/bg-13-1209-2016

Reeburgh, W. S. 2007. Oceanic methane biogeochemistry. Chem. Rev. 107: 486-513. doi:10.1021/cr050362v

Reeburgh, W. S., B. B. Ward, S. C. Whalen, K. A. Sandbeck, K. A. Kilpatrickt, and L. J. Kerkhof. 1991. Black Sea methane geochemistry. Deep-Sea Res. Part I 38: S1189-S1210. doi:10.1016/S0198-0149(10)80030-5

Reed, A. J., R. Dorn, C. L. Van Dover, R. A. Lutz, and C. Vetriani. 2009. Phylogenetic diversity of methanogenic, sulfate-reducing and methanotrophic prokaryotes from deep-sea hydrothermal vents and cold seeps. Deep-Sea Res. Part II 56: 1665-1674. doi:10.1016/j.dsr2.2009.05.012

Rehder, G., R. S. Keir, E. Suess, and T. Pohlmann. 1998. The multiple sources and patterns of methane in North Sea waters. Aquat. Geochem. 4: 403-427. doi:10.1023/A: 1009644600833

Røy, H., H. S. Weber, I. H. Tarpgaard, T. G. Ferdelman, and B. B. Jørgensen. 2014. Determination of dissimilatory sulfate reduction rates in marine sediment via radioactive ${ }^{35} \mathrm{~S}$ tracer. Limnol. Oceanogr. Methods 12: 196-211.

Ruff, S. E., J. Arnds, K. Knittel, R. Amann, G. Wegener, A. Ramette, and A. Boetius. 2013. Microbial communities of deep-sea methane seeps at Hikurangi continental margin (New Zealand). PloS One 8: e72627. doi:10.1371/ journal.pone.0072627

Schmale, O., I. Leifer, J. S. V. Deimling, C. Stolle, S. Krause, K. Kießlich, A. Frahm, and T. Treude. 2015. Bubble transport mechanism: Indications for a gas bubble-mediated inoculation of benthic methanotrophs into the water column. Cont. Shelf Res. 103: 70-78. doi:10.1016/j.csr.2015.04.022

Schneider Von Deimling, J., J. Brockhoff, and J. Greinert. 2007. Flare imaging with multibeam systems: Data processing for bubble detection at seeps. Geochem. Geophys. Geosyst. 8: 1-7.

Schneider Von Deimling, J. S. V., P. Linke, M. Schmidt, and G. Rehder. 2015. Ongoing methane discharge at well site 22/4b (North Sea) and discovery of a spiral vortex bubble plume motion. Mar. Pet. Geol. 68: 718-730. doi:10.1016/ j.marpetgeo.2015.07.026

Semrau, J. D., A. A. DiSpirito, and S. Yoon. 2010. Methanotrophs and copper. FEMS Microbiol. Rev. 34: 496-531. doi:10.1111/j.1574-6976.2010.00212.x
Shakhova, N., I. Semiletov, A. Salyuk, V. Yusupov, D. Kosmach, and O. Gustafsson. 2010. Extensive methane venting to the atmosphere from sediments of the East Siberian Arctic Shelf. Science 327: 1246-1250. doi: $10.1126 /$ science. 1182221

Sommer, S., and others. 2009. Seabed methane emissions and the habitat of frenulate tubeworms on the Captain Arutyunov mud volcano (Gulf of Cadiz). Mar. Ecol. Prog. Ser. 382: 69-86. doi:10.3354/meps07956

Sommer, S., M. Schmidt, and P. Linke. 2015. Continuous inline tracking of dissolved methane plume at a blow out site in the North Sea UK-water column stratification impedes immediate methane release into the atmosphere. Mar. Pet. Geol. 68: 766-775. doi:10.1016/j.marpetgeo. 2015.08.020

Steeb, P., P. Linke, and T. Treude. 2014. A sediment flowthrough system to study the impact of shifting fluid and methane flow regimes on the efficiency of the benthic methane filter. Limnol. Oceanogr. Methods 12: 25-45. doi:10.4319/lom.2014.12.25

Steinle, L., and others. 2015. Water column methanotrophy controlled by a rapid oceanographic switch. Nat. Geosci. 8: 378-382. doi:10.1038/ngeo 2420

Tamura, K., G. Stecher, D. Peterson, A. Filipski, and S. Kumar. 2013. MEGA6: Molecular evolutionary genetics analysis version 6.0. Mol. Biol. Evol. 30: 2725-2729. doi: 10.1093/molbev/mst197

Tavormina, P. L., W. Ussler, and V. J. Orphan. 2008. Planktonic and sediment-associated aerobic methanotrophs in two seep systems along the North American margin. Appl. Environ. Microbiol. 74: 3985-3995. doi:10.1128/AEM.00069-08

Tavormina, P. L., W. Ussler, S. B. Joye, B. K. Harrison, and V. J. Orphan. 2010. Distributions of putative aerobic methanotrophs in diverse pelagic marine environments. ISME J. 4: 700-710. doi:10.1038/ismej.2009.155

Tavormina, P. L., R. Hatzenpichler, S. McGlynn, G. Chadwick, K. S. Dawson, S. A. Connon, and V. J. Orphan. 2015. Methyloprofundus sedimenti gen. nov., sp. nov., an obligate methanotroph from ocean sediment belonging to the "deep sea-1" clade of marine methanotrophs. Int. J. Syst. Evol. Microbiol. 65: 251-259. doi:10.1099/ijs. 0.062927-0

Treude, T., A. Boetius, K. Knittel, K. Wallmann, and B. Barker Jørgensen. 2003. Anaerobic oxidation of methane above gas hydrates at Hydrate Ridge, NE Pacific Ocean. Mar. Ecol. Prog. Ser. 264: 1-14. doi:10.3354/meps264001

Treude, T., J. Niggemann, J. Kallmeyer, P. Wintersteller, C. J. Schubert, A. Boetius, and B. B. Jørgensen. 2005. Anaerobic oxidation of methane and sulfate reduction along the Chilean continental margin. Geochim. Cosmochim. Acta 69: 2767-2779. doi:10.1016/j.gca.2005.01.002

Treude, T., V. Orphan, K. Knittel, A. Gieseke, C. H. House, and A. Boetius. 2007. Consumption of methane and $\mathrm{CO}_{2}$ by methanotrophic microbial mats from gas seeps of the 
anoxic Black Sea. Appl. Environ. Microbiol. 73: 22712283. doi:10.1128/AEM.02685-06

Tsutsumi, M., T. Iwata, H. Kojima, and M. Fukui. 2011. Spatiotemporal variations in an assemblage of closely related planktonic aerobic methanotrophs. Freshwater Biol. 56: 342-351. doi:10.1111/j.1365-2427.2010.02502.x

Urakami, T., J. Sasaki, K. I. Suzuki, and K. Komagata. 1995. Characterization and description of Hyphomicrobium denitrificans sp. nov. Int. J. Syst. Bacteriol. 45: 528-532. doi: 10.1099/00207713-45-3-528

Vielstädte, L., and others. 2015. Quantification of methane emissions at abandoned gas wells in the Central North Sea. Mar. Pet. Geol. 68: 848-860. doi:10.1016/j.marpetgeo.2015.07.030

Vuilleumier, S., and othres. 2011. Complete genome sequence of the chloromethane-degrading Hyphomicrobium sp. strain MC1. J. Bacteriol. 193: 5035-5036. doi: 10.1128/JB.05627-11

Wallmann, K., G. Aloisi, M. Haeckel, A. Obzhirov, G. Pavlova, and P. Tishchenko. 2006. Kinetics of organic matter degradation, microbial methane generation, and gas hydrate formation in anoxic marine sediments. Geochim. Cosmochim. Acta 70: 3905-3927. doi:10.1016/j.gca.2006.06.003

Wallmann, K., E. Pinero, E. Burwicz, M. Haeckel, C. Hensen, A. Dale, and L. Ruepke. 2012. The global inventory of methane hydrate in marine sediments: A theoretical approach. Energies 5: 2449-2498. doi:10.3390/en5072449

Wang, P., F. Wang, M. Xu, and X. Xiao. 2004. Molecular phylogeny of methylotrophs in a deep-sea sediment from a tropical west Pacific Warm Pool. FEMS Microbiol. Ecol. 47: 77-84. doi:10.1016/S0168-6496(03)00252-6

Watsuji, T.-O., A. Yamamoto, K. Motoki, K. Ueda, E. Hada, Y. Takaki, S. Kawagucci, and K. Takai. 2014. Molecular evidence of digestion and absorption of epibiotic bacterial community by deep-sea crab Shinkaia crosnieri. ISME J. 9: 1-11.

Whiticar, M. J. 1999. Carbon and hydrogen isotope systematics of bacterial formation and oxidation of methane. Chem. Geol. 161: 291-314. doi:10.1016/S0009-2541(99) 00092-3

Wilfert, P., S. Krause, V. Liebetrau, J. Schönfeld, M. Haeckel, P. Linke, and T. Treude. 2015. Response of anaerobic methanotrophs and benthic foraminifera to 20 years of methane emission from a gas blowout in the North Sea. Mar. Pet. Geol. 68: 731-742. doi:10.1016/j.marpetgeo.2015.07.012

Wilkins, D., E. van Sebille, S. R. Rintoul, F. M. Lauro, and R. Cavicchioli. 2013. Advection shapes Southern Ocean microbial assemblages independent of distance and environment effects. Nat. Comm. 4: 2457. doi:10.1038/ncomms3457

Wilson, D. S., I. Leifer, and E. Maillard. 2015. Megaplume bubble process visualization by 3D multibeam sonar mapping. Mar. Pet. Geol. 68: 753-765. doi:10.1016/j.marpetgeo.2015.07.007

Wise, M. G., J. V. McArthur, and L. J. Shimkets. 1999. Methanotroph diversity in landfill soil: Isolation of novel type I and type II methanotrophs whose presence was suggested by culture-independent 16S ribosomal DNA analysis. Appl. Environ. Microbiol. 65: 4887-4897.

Woebken, D., H. Teeling, P. Wecker, A. Dumitriu, I. Kostadinov, E. F. DeLong, R. Amann, and F. O. Glöckner. 2007. Fosmids of novel marine Planctomycetes from the Namibian and Oregon coast upwelling systems and their cross-comparison with planctomycete genomes. ISME J. 1: 419-435. doi:10.1038/ ismej.2007.63

\section{Acknowledgments}

We thank the Captain and crew of R/V Celtic Explorer, the ROV team (GEOMAR), and the scientific party of cruise CE12010 for the excellent support at sea. Additional thanks go to G. Schüßler, M. Dibbern, B. Domeyer, A. Bleyer, and A. Bodenbinder for technical support. This work received financial support through a D-A-CH project funded by the Swiss National Science Foundation and the German Research foundation (grants 200021L_138057 and 200020_159878/1). Further support was provided through the EU COST Action PERGAMON (ESSEM 0902). The project's ship time and transportation was funded by EUROFLEETS (grant 228344), with work being conducted in the framework of the ECO2 project (FP7, grant 265847). Further support came from the Cluster of Excellence "The Future Ocean" funded by the German Research Foundation.

\section{Conflict of Interest}

None declared.
Submitted 05 February 2016 Revised 08 June 2016 Accepted 15 July 2016

Associate editor: Leila Hamdan 